\title{
Ectomycorrhizal diversity at five different tree species in forests of the Taunus Mountains in Central Germany
}

\author{
Uwe Schirkonyer $^{1^{*}}$, Christine Bauer ${ }^{2}$, Gunter M. Rothe ${ }^{1}$ \\ ${ }_{1}^{1}$ Institute of General Botany, Johannes Gutenberg-University, Mainz, Germany; \\ *Corresponding Author: uwe@schirkonyer.de \\ ${ }^{2}$ Institute of Molecular Biology, Johannes Gutenberg-University, Mainz, Germany
}

Received 9 December 2012; revised 10 January 2013; accepted 19 January 2013

\section{ABSTRACT}

Ectomycorrhizal fungi were investigated on five different forest tree species growing in pure stands on the south slope of the Taunus Mountains, which are situated at the northern end of the Rhine rift valley in Central Germany. Mycorrhizal fungi accompanying the genus Xerocomus were identified and their frequencies counted. Using ITS markers, 22 different fungal species were identified down to species level and 6 down to genus level. On European beech (Fagus sylvatica) 16 fungal species and 4 genera were identified and on Sessile oak (Quercus petraea) 16 ectomycorrhizal species and 2 genera were determined. On both deciduous trees we observed exclusively: Cortinarius subsertipes, Genea hispidula, Lactarius quietus, Tylopilus felleus and a Melanogaster genus. On Norway spruce (Picea abies) we identified 13 different mycorrhizal species and 3 different genera, on Silver fir (Abies alba) 12 species and 3 genera, and in association with European larch (Larix decidua) 11 species and 3 genera. On these conifers Cortinarius anomalus, Lactarius necator and a Piloderma genus occurred exclusively. Comparisons with published data of ectomycorrhizal diversity on the same five tree species, growing in different areas of Germany and Europe, led to the conclusion that there is relative site specificity for ectomycorrhizal communities. Upper soil compartments of the stands investigated in the Taunus Mountains suffer from soil acidification ( $\mathrm{pH}-\mathrm{H}_{2} \mathrm{O} \sim 3.7$ to $\left.\sim 4.8\right)$. However, a clear correlation between upper soil $\mathrm{pH}$-values and fungal diversity was not observed. On the other hand, nitrate concentrations in upper soil compartments $(\sim 26$ to $\sim 91 \mathrm{~kg}$ $\mathrm{NO}_{3}{ }^{-} / \mathrm{ha}$ ) were higher in older stands as com- pared to younger ones. Higher nitrate concentrations in upper soils correlated with lower numbers of mycorrhizal individuals.

Keywords: Conifers; Ectomycorrhiza; Deciduous Trees; Forests; Nitrogen; Population Diversity; Taunus Mountains

\section{INTRODUCTION}

Most European tree species form a symbiosis with higher soil fungi in the root tip region [1,2]. This symbiosis with asco- and basidiomycota, but also with mitosporic fungi, referred to as ectomycorrhiza, induces an exchange of various metabolites between both symbiotic partners [3-9] but also alters root growth [10,11]. The extension of long roots is inhibited and coralloid branched short roots are formed [12].

The hyphae of ectomycorrhizal fungi are dikaryotic and sexual reproduction is performed via the production of haploid spores in above ground fruiting bodies [13]. Those ectomycorrhizal fungi that do not form fruiting bodies cannot be classified as species in the traditional meaning. They are named Fagirhiza spp., Pinirhiza spp. etc. [12] in relation to the host tree species on which they occur and their morphological traits.

Phytobionts and phycobionts in an ectomycorrhizal community possess their own systems to take up nitrate from soils and to reduce nitrate to $\mathrm{R}-\mathrm{NH}_{2}$ [14-16]. Under the conditions of low soil nutrient, however, ectomycorrhizal fungi support the uptake of nitrate, phosphate and water to their hosts, obtaining carbohydrates from these in return [17]. An excess of nitrogen $\left(\mathrm{NH}_{4}^{+} / \mathrm{NO}_{3}^{-}\right)$ in upper forest soils seems to decouple this system, consequently leading to a serious reduction of the number of ectomycorrhizal individuals per species $[18,19]$. At present, the average $\mathrm{N}$-input into German forest ecosystems amounts to about $18 \mathrm{~kg} \mathrm{~N} / \mathrm{ha}$ and year, which is close to what is presently believed the upper tolerable limit of 20 
$\mathrm{kg} \mathrm{N} /$ ha year [20]. In 2009 in forests of the State of Hesse in Central Germany, the average nitrogen $\left(\mathrm{NH}_{4}-\mathrm{N}\right.$ plus $\mathrm{NO}_{3}-\mathrm{N}$ ) input amounted to $24 \mathrm{~kg} \mathrm{~N} /$ ha under Norway spruce (Picea abies) and $17 \mathrm{~kg} / \mathrm{ha}$ under European beech (Fagus sylvatica) [20]. Our own investigations show that nitrogen contents in upper soils of forest stands in the Taunus Mountains vary depending on stand age, partly transgressing the threshold value.

This situation prompted us to determine the mycorrhizal species and their frequency found during a search for ectomycorrhizae of the genus Xerocomus on root tips of European beech (Fagus sylvatica), Sessile oak (Quercus petraea), Norway spruce (Picea abies), Silver fir (Abies alba) and European larch (Larix decidua) growing in the Taunus Mountains. The data obtained are compared with those reported for some other German and European forest ecosystems. Furthermore, fungal diversity and number of individuals per fungal species, respectively genus are correlated to upper soil $\mathrm{pH}$-values, nitrogen contents and stand age.

\section{MATERIALS AND METHODS}

\subsection{Stand Characteristics}

Root samples and fruiting bodies were collected in five different forest stands on the south-side of the Taunus Mountains, situated in the southern part of the state of Hesse, Germany. The GPS coordinates of the study sites are given in Table 1. Mycorrhizal roots were sampled in spring and autumn in forest stands belonging to the forest districts Wiesbaden-Chauseehaus and Königstein. Mycorrhizal roots were collected from pure stands of Abies alba (Mill.), Fagus sylvatica (L.), Larix decidua (Mill.), Picea abies ((L.) H Karst.) and Quercus petraea, (Matt.) Liebl.)).

The number of sampled Silver firs and Sessile oaks is lower compared to European beech, Norway spruce and European larch in the Taunus Mountains because in this area there are almost no pure stands of Silver fir and Sessile oak. During a six week sampling-period an average of 120 mycorrhizal samples were collected.

\subsection{Sampling of Mycorrhizae}

Mycorrhizal root samples were collected from trees that were at least $10 \mathrm{~m}$ apart. The collected samples were put in labelled plastic bags and stored on ice in a cooling container. In the laboratory samples were washed in iced water, sorted under a stereomicroscope at $25 \times$ magnification, according to morphological criteria described by Agerer [12], and then stored at $-20^{\circ} \mathrm{C}$. Final identification was performed by amplification of the ITS region, using the primer pair ITS1 [21] and ITS4b or ITS1F/ ITS4 [22], and restriction of the amplified DNA with Hinf $I$ as described by Haese and Rothe [23]. The collected fruiting bodies were transported in paper bags and later cut into halves. One part was frozen in liquid nitrogen while the other half was dried at $50^{\circ} \mathrm{C}$ for three days.

\subsection{Soil Parameters}

\subsection{1. $\mathrm{pH}$-Values}

Six 20-g samples of upper soil (0 to $5 \mathrm{~cm}$ soil depth) were collected from each stand, sieved and dried at $30^{\circ} \mathrm{C}$ for three days. Dry soil samples were bisected and to one half $25 \mathrm{ml}$ of distilled water added, while to the remaining half $25 \mathrm{ml}$ of $10 \mathrm{mM} \mathrm{CaCl} 2$ were added. Samples were shaken at $200 \mathrm{rpm}$ for an hour on a shaker, then the soil was allowed to settle for 20 minutes and then $\mathrm{pH}$ values were measured (Digital-pH-meter 646, Knick, Germany). Before measurements the $\mathrm{pH}$-electrode was calibrated with a calibration-buffer at $\mathrm{pH} 4$ and $\mathrm{pH} 7$. Measurements were performed at $20^{\circ} \mathrm{C}$.

\subsubsection{Upper Soil Ammonium and Nitrate Concentrations}

Determinations were performed using colorimetric kits

Table 1. Characteristics of the investigated stands in the Taunus Mountains.

\begin{tabular}{|c|c|c|c|c|c|c|}
\hline \multirow{2}{*}{\multicolumn{2}{|c|}{$\begin{array}{c}\text { Forest district } \\
\text { Near the city of }\end{array}$}} & \multicolumn{4}{|c|}{ Wiesbaden-Chausseehaus } & \multirow{3}{*}{$\begin{array}{l}\text { Königstein } \\
\text { Königstein } \\
50^{\circ} 12.623^{\prime}\end{array}$} \\
\hline & & \multicolumn{2}{|c|}{ Taunusstein } & \multicolumn{2}{|c|}{ Glashütten } & \\
\hline \multirow{2}{*}{ GPS } & $\mathrm{N}$ & $50^{\circ} 07.875^{\prime}$ & $50^{\circ} 07.875^{\prime}$ & $50^{\circ} 13.262^{\prime}$ & $50^{\circ} 13.508^{\prime}$ & \\
\hline & $\mathrm{E}$ & $08^{\circ} 10.382^{\prime}$ & $08^{\circ} 10.705^{\prime}$ & $08^{\circ} 23.920^{\prime}$ & $08^{\circ} 24.018^{\prime}$ & $08^{\circ} 25.992^{\prime}$ \\
\hline \multicolumn{2}{|c|}{ Tree species } & $\begin{array}{c}\text { Norway spruce } \\
\text { (Picea abies) }\end{array}$ & $\begin{array}{l}\text { European beech } \\
\text { (Fagus sylvatica) }\end{array}$ & $\begin{array}{c}\text { Silver fir } \\
(\text { Abies alba })\end{array}$ & $\begin{array}{c}\text { Sessile oak } \\
\text { (Quercus petraea) }\end{array}$ & $\begin{array}{l}\text { European larch } \\
\text { (Larix decidua) }\end{array}$ \\
\hline \multicolumn{2}{|c|}{ Sampling periods } & $\begin{array}{c}\text { April-June/Sept.-Nov. } \\
\text { 2006-2010 }\end{array}$ & $\begin{array}{c}\text { April-June/Sept.-Nov. } \\
\text { 2006-2010 }\end{array}$ & $\begin{array}{c}\text { June/July } \\
\text { 2009-2010 }\end{array}$ & $\begin{array}{l}\text { May } \\
2010\end{array}$ & $\begin{array}{c}\text { Sept.-Nov. } \\
\text { 2005, June } 2010\end{array}$ \\
\hline \multicolumn{2}{|c|}{ Number of samplings } & 8 & 8 & 2 & 1 & 10 \\
\hline \multicolumn{2}{|c|}{ Sampled trees } & 190 & 189 & 42 & 36 & 115 \\
\hline \multicolumn{2}{|c|}{ Age (years) } & 87 & 168 & 126 & 179 & 45 \\
\hline
\end{tabular}


obtained from Merck (Darmstadt, Germany). Ammonium contents were determined with the "AmmoniumTest" (Spectroquant 114752) converting ammonium ions into ammonia in a strong alkaline solution and chlorinating this to mono-chloramine which forms a blue indophenol derivative with thymole.

At each stand six samples of the upper soil compartment were taken. Five grams of dried soil were mixed with $20 \mathrm{ml}$ of $12.5 \mathrm{mM} \mathrm{CaCl}_{2}$ and shaken vigorously at $200 \mathrm{rpm}$ on a shaker for $30 \mathrm{~min}$. After $10 \mathrm{~min}$ the slurry was filtrated and then $5 \mathrm{ml}$ of clear sample solution were pipetted into a reagent vial, used to determine ammonium concentrations at RT. Then $0.60 \mathrm{ml}$ of reagent " $\mathrm{NH}_{4}-1$ " was pipetted into that vial and the solutions mixed. After that, one micro spoon full of reagent " $\mathrm{NH}_{4}-2$ " was added and the mixture rigorously shaken until the reagent was fully dissolved. After a reaction time of $5 \mathrm{~min}, 4$ drops of reagent " $\mathrm{NH}_{4}-3$ " were added. After mixing that solution, 5 min later its green-blue colour intensity was quantified photometrically at 690 nm against a blank.

Nitrate concentrations were determined by use of the "Nitrat-Test" (Spectroquant 114773), making use of the fact that nitrate-ions form in a concentrated sulphuric acid together with a benzoic acid derivative a red nitro compound that can be photometrically quantified: one full micro spoon of reagent " $\mathrm{NO}_{3}-1 \mathrm{~A}$ " was put into a dry reagent vial that could be closed with a screw cab. Then $5 \mathrm{ml}$ of reagent " $\mathrm{NO}_{3}-2 \mathrm{~A}$ " were added and the mixture rigorously shaken until the reagent had dissolved completely. Then $1.5 \mathrm{ml}$ sample solution (treated as described for the determination of ammonium) was carefully added by slowly running down the inner side of the reagent vial held in a sloping position. Immediately the screwed vial was shaken rigorously. After a 10 min reaction time, the colour intensity was measured in a photometer at $517 \mathrm{~nm}$ against a blank.

Nitrogen concentrations were calculated using the equation: $\mathrm{m}_{\mathrm{N}}=\beta_{\mathrm{N}} * \mathrm{~F}^{*} \mathrm{~d}^{*} \mathrm{ps}[\mathrm{kg} / \mathrm{ha}]$, with: $\beta_{\mathrm{N}}=$ nitrogen concentration in sample solution $(\mathrm{mg} \mathrm{N} / \mathrm{ml}), \mathrm{F}=$ factor resulting from the volume $\mathrm{V}_{\mathrm{e}}(\mathrm{ml})$ used to extract a certain amount of dry soil $\mathrm{S}_{\mathrm{d}}(\mathrm{g})\left(\mathrm{F}=\mathrm{V}_{\mathrm{e}} / \mathrm{S}_{\mathrm{d}}(\mathrm{ml} / \mathrm{g})\right), \mathrm{d}=$ soil depth that was probed $(\mathrm{dm})$, equivalent to $5 \mathrm{~cm}(=\mathrm{dm}=$ $0.5)$ and $\mathrm{ps}=$ density of dry soil at 0 to $5 \mathrm{~cm}$ soil depth, equivalent to $1.3\left(\mathrm{~g} / \mathrm{cm}^{3}\right)$. Thus $\mathrm{N}(\mathrm{kg} / \mathrm{ha})=2.6 * \mathrm{~N}(\mathrm{mg} /$ $\mathrm{ml})$.

\subsection{DNA Extraction}

Total DNA was extracted according to Haese and Rothe [23] with a modified CTAB (cetyltrimetyl ammonium bromide)-protocol [24]: A single mycorrhizal root tip was put into a sterile $1.5 \mathrm{ml}$ reaction tube, frozen in liquid nitrogen and then homogenized by hand with a plastic minipestle. To the resulting powdered material
$300 \mu \mathrm{l}$ of extraction buffer $[10 \mathrm{mM}$ Tris- $\mathrm{HCl}(\mathrm{pH} 8.0)$, $1.4 \mathrm{M} \mathrm{NaCl}, 20 \mathrm{mM} \mathrm{Na}$-EDTA (ethylendiamine tetra acetic acid) and $2 \%(\mathrm{w} / \mathrm{v}) \mathrm{CTAB}$ ] were added, then the mixture was incubated for $60-75 \mathrm{~min}$ at $65^{\circ} \mathrm{C}$ in a water bath with vortexing at approximately every 15 minutes for $10 \mathrm{sec}$. The resulting slurry was centrifuged for $5 \mathrm{~min}$ at $13,000 \mathrm{x} \mathrm{g}$ at room temperature and the supernatant transferred into a sterile $1.5 \mathrm{ml}$ reaction tube. Then 390 $\mu \mathrm{l}$ of isopropanol $(99.7 \%)$ and $20 \mu \mathrm{l}$ of sodium acetate (3 M) were added, the tube was inverted ten times and subsequently stored over night at $-20^{\circ} \mathrm{C}$. The next day nucleic acids were precipitated by centrifugation at $10,000 \mathrm{x}$ $\mathrm{g}$ at $4^{\circ} \mathrm{C}$ for $10 \mathrm{~min}$. The supernatant was removed and $600 \mu \mathrm{l}$ of $70 \%$ ethanol were added to the pellet while keeping the mixture for five min at room temperature. The mixture was then centrifuged for $2 \mathrm{~min}$ at $10,000 \mathrm{x} \mathrm{g}$ at RT. This procedure was repeated once and then the supernatant was air-dried for $20 \mathrm{~min}$. The resulting pellet was re-suspended in $100 \mu$ Tris-EDTA-buffer of $\mathrm{pH} 8.0$ (10 mM Tris-HCl, $1 \mathrm{mM} \mathrm{Na}$-EDTA) and then warmed to $65^{\circ} \mathrm{C}$ for $60 \mathrm{~min}$ while vortexing the mixture four to six times for $10 \mathrm{sec}$. The resulting solution was diluted 1:50 with sterile HPLC-water and stored at $-20^{\circ} \mathrm{C}$.

\subsection{PCR-RFLP Analysis}

To identify mycorrhizal samples and fruiting bodies, the multicopy ITS region of their ribosomal DNA (rDNA) was amplified and sequenced. The rDNA repeats, comprising the $18 \mathrm{~S}$ rRNA gene, the ITS-1-spacer, the $5.8 \mathrm{~S}$ rRNA, the ITS-2-spacer and the 28S rRNA gene, was amplified using the primer pair ITS1 [21] and ITS4b [22]. Primer ITS1 binds to the 3'-end of the 18S rRNA gene and primer ITS $4 \mathrm{~b}$ binds to the 5 '-end of the $28 \mathrm{~S}$ rRNA gene. If no PCR product resulted, the primer pair ITS1F/ ITS4 was used [22].

A $20 \mu \mathrm{l}$ PCR reaction mixture contained $2 \mu \mathrm{ldNTPs}$ (200 pM of each), $1 \mu$ l of each primer ( 1 pM per primer), $0.2 \mu \mathrm{l}$ BioTherm polymerase (1 Unit, Genecraft, Münster, Germany), $2 \mu \mathrm{l}$ of the appropriate buffer (10x, containing $15 \mathrm{mM} \mathrm{MgCl}_{2}$ ), $3.8 \mu \mathrm{l}$ HPLC- $\mathrm{H}_{2} \mathrm{O}$ and $10 \mu \mathrm{l}$ of DNA solution. Control reactions contained autoclaved water instead of extracted DNA. The following temperatures and reaction times were used to amplify the ITS region: a) 3 min denaturation at $94^{\circ} \mathrm{C}$, b) 35 amplification cycles $\left(45 \mathrm{sec}\right.$ at $94^{\circ} \mathrm{C}, 45 \mathrm{sec}$ at $58^{\circ} \mathrm{C}$ and $90 \mathrm{sec}$ at $72^{\circ} \mathrm{C}$ ) and c) a final extension for $10 \mathrm{~min}$ at $72^{\circ} \mathrm{C}$. Then using the restriction enzyme Hinf I, PCR products were cut without further purification ( 5 Units Hinf I per $20 \mu \mathrm{l} \mathrm{PCR} \mathrm{reac-}$ tion mixture and $5 \mathrm{~h}$ incubation at $37^{\circ} \mathrm{C}$ ).

\subsection{Sequencing}

Sequencing of PCR products was done by GENterprise-Genomics (Mainz, Germany). For fungal identifi- 
cation, BLAST searches were carried out against the NCBI (http://www.ncbi.nlm.nih.gov/) and UNITE (http://unite.ut.ee) public sequence databases. Sequences were assigned to matching species names when the BLAST matches showed identities higher than $97 \%$ and scores higher than 900 bits. The name suggested by UNITE, a database for EM fungi [25], was used preferentially and that of NCBI only if there was no entry in UNITE. If no appropriate match was found, the sequence was assigned to a higher taxonomic level (genus) and was called spp.

\subsection{Calculation of Species Diversity}

To quantify species diversities the following indices were calculated: Shannon index $\left(\mathrm{H}^{\prime}\right)$, maximum value of the Shannon index $\left(\mathrm{H}_{\max }\right)$ and Shannon equitability (evenness, E). The Shannon index results from $H^{\prime}=-\sum$ pi lnpi, with ln, natural logarithm and $\mathrm{pi}=\mathrm{ni} / \mathrm{N}$, with $\mathrm{ni}=$ number of individuals per species and $\mathrm{N}=$ number of individuals per forest stand. The resulting product is summed across species and multiplied by -1 [26,27]. The maximum value of the Shannon index results from $\mathrm{H}_{\max }=\ln \mathrm{S}$, with $\ln$, natural logarithm and $\mathrm{S}=$ number of identified mycorrhizal species per forest stand. Shannon's index of equitability (evenness) of a community can be represented by Pielou's evenness index $(\mathrm{E}=\mathrm{H}$ '/ $\mathrm{H}_{\max }$ ), where $\mathrm{H}^{\prime}$ is the number derived from the Shannon diversity index and $\mathrm{H}_{\max }$ is the maximum value of $\mathrm{H}^{\text {' }}$ [28]. Evenness ranges from zero to one, with zero signifying no evenness and one, a complete evenness.

\section{RESULTS}

\subsection{Soil Parameters}

The five different stands in the Taunus Mts. that were investigated for mycorrhizal richness were also studied with respect to upper soil $(0-5 \mathrm{~cm}) \mathrm{pH}$-values and nitrogen contents.

\subsubsection{Soil pH}

The upper soils of the five investigated stands suffer under soil acidification as can be taken from the $\mathrm{pH}$ values listed in Table 2. Proton concentrations ranged at average from $\mathrm{pH}-\mathrm{H}_{2} \mathrm{O} 4.78$ to $\mathrm{pH}-\mathrm{H}_{2} \mathrm{O}$ 3.66. Potential acidification as indicated by $\mathrm{pH}-\mathrm{CaCl}_{2}$ values were at average 0.51 units lower than the actual $\mathrm{pH}-\mathrm{H}_{2} \mathrm{O}$ values (Table 2).

According to Ulrich [29] proton concentrations of soils can be attributed to five different buffer systems: 1) the carbonic acid-carbonate buffer ( $\mathrm{pH} 8.6$ to 6.2$), 2)$ the carbonic acid-silicate buffer ( $\mathrm{pH} 6.2$ to 5.0$), 3)$ the exchange buffer ( $\mathrm{pH} 5.0$ to 4.2), 4) the aluminium buffer ( $\mathrm{pH} 4.2$ to 3.0) and 5) the iron buffer $(\mathrm{pH}<3.0)$. Thus the roots of the investigated Norway spruce and fir trees grow in the upper soil under the influence of the exchange buffer system, i.e. they grow under the influence of a "moderate acid" soil buffer, while the roots of European beech, European larch and Sessile oak are under the influence of the "very acid" aluminium buffer-system. Under natural conditions, soil acidification ends with the carbonic acid-silicate buffer system. Lower $\mathrm{pH}$ soil values are caused by the input of strong inorganic acids such as nitric acid which is input into forest ecosystems through acid rain.

In the investigated stands in the Taunus Mountains, soil acidification in the upper soils increases with tree age (Figure 1).

Assuming a linear correlation between tree age, respectively stand age and soil $\mathrm{pH}-\mathrm{H}_{2} \mathrm{O}$-values in a soil depth of $0-5 \mathrm{~cm}$, it can be estimated that the $\mathrm{pH}$-value decreased on average during the last 100 years by about $0.34 \mathrm{pH}$ units; if the larch stand is excluded from the calculation, a decrease of 1.2 units is obtained (Figure 1).

Table 2. $\mathrm{pH}$-values of upper soils $(0-5 \mathrm{~cm})$ of the five forest stands located in the Taunus Mts.

\begin{tabular}{ccc}
\hline Tree species & $\mathbf{p H}-\mathbf{H}_{\mathbf{2}} \mathbf{O}$ & $\mathbf{p H}-\mathbf{C a C l}_{\mathbf{2}}$ \\
\hline Abies alba & $4.28 \pm 0.17$ & $3.71 \pm 0.14$ \\
Fagus sylvatica & $3.96 \pm 0.33$ & $3.58 \pm 0.33$ \\
Larix decidua & $3.80 \pm 0.14$ & $3.04 \pm 0.19$ \\
Picea abies & $4.78 \pm 0.37$ & $4.66 \pm 0.53$ \\
Quercus petraea & $3.66 \pm 0.18$ & $2.95 \pm 0.29$ \\
a.m \pm S D & $4.10 \pm 0.47$ & $3.61 \pm 0.70$ \\
\hline
\end{tabular}

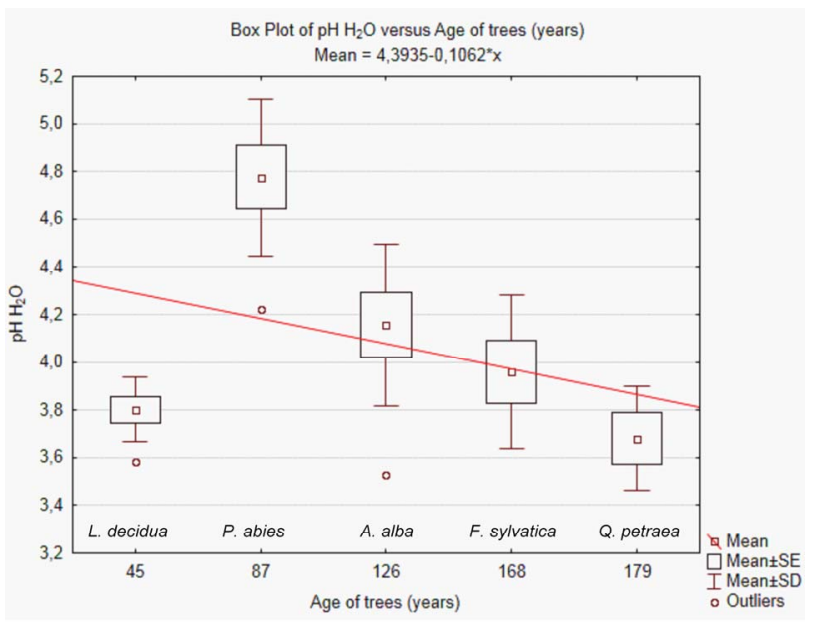

Figure 1. Age of the tree stands and their $\mathrm{pH}_{\mathrm{H} 20}$-values measured in 2012. The age of the tree stands in the Taunus Mts. and upper soil $(0-5 \mathrm{~cm}) \mathrm{pH}_{\mathrm{H} 20}$-values were measured in 2012. The graph was plotted by use of the software STATISTICA (StatSoft http://www.statsoft.de). SE = standard error, $\mathrm{SD}=$ standard deviation (coefficient 1 for SE and SD). The coefficient for outliers is 1.5 . 


\subsubsection{N-Concentrations}

Average ammonium concentrations in upper soils of the five stands investigated in the Taunus Mts. amounted to $2.52 \pm 1.61 \mathrm{~kg} \mathrm{NH} \mathrm{NH}_{4}^{+}$/ha while average nitrate concentrations were $52.53 \pm 46.74 \mathrm{~kg} \mathrm{NO}-/$ ha. From these values an average nitrogen content of $14.05 \pm 10.94 \mathrm{~kg}$ $\mathrm{N} / \mathrm{ha}$ (Table 3) was obtained. Ammonium concentrations are relatively constant in soils of the five stands, but nitrate concentrations are stand-dependent. Strongest are the Sessile oak stand and the European beech stand loaded with nitrogen showing total nitrogen concentrations of about $20 \mathrm{~kg} \mathrm{~N} / \mathrm{ha}$ (Table 3). The fir, larch and spruce stands show decreasing nitrogen concentrations, ranging from about 13 to about $8 \mathrm{~kg} \mathrm{~N} / \mathrm{ha}$ (Table 3).

Total nitrogen concentrations ( $\mathrm{kg} \mathrm{N} / \mathrm{ha}$ ) increase with stand age (Figure 2). Assuming a linear increase in $\mathrm{N}$-concentrations over the last 134 years, the average net soil nitrogen contend per year increased by about $0.13 \mathrm{~kg}$ $\mathrm{N} / \mathrm{ha}$, starting at a concentration of about $7 \mathrm{~kg} \mathrm{~N} / \mathrm{ha}$ (Figure 2). Since nitrogen concentrations are higher and $\mathrm{pH}$-values lower in the older compared to the younger stands, soil acidification can mainly be attributed to an accumulation of nitric acid.

\subsection{Molecular Identification}

\subsubsection{Length of ITS-Fragments}

The multi-copy ITS rDNA fragment can be used to identify ectomycorrhizal fungi [30-32]. The length of the amplified ITS regions of mycorrhizae investigated in the Taunus Mountains using the primer pair ITS1/ITS4b ranged from 700 to $900 \mathrm{bp}$ (Table 4). Using this primer pair in Xerocomus chrysenteron as well as in Boletus edulis and Xerocomus pruinatus a fragment of $900 \mathrm{bp}$ was amplified, corresponding to the data of Haese and Rothe [23]. The length of the amplified ITS-region in Xerocomus badius is $800 \mathrm{bp}$.

Table 3. Ammonium, nitrate and total nitrogen concentrations in upper soils $(0-5 \mathrm{~cm})$.

\begin{tabular}{cllllll}
\hline $\begin{array}{c}\text { Tree } \\
\text { species }\end{array}$ & \multicolumn{2}{c}{$\mathbf{N H}^{+}$} & \multicolumn{2}{c}{ NO $_{3}^{-}$} & \multicolumn{2}{c}{$\mathbf{N}$} \\
\hline & $\mathrm{mg} / \mathrm{l}$ & $\mathrm{kg} / \mathrm{ha}$ & $\mathrm{mg} / 1$ & $\mathrm{~kg} / \mathrm{ha}$ & $\mathrm{mg} / \mathrm{l}$ & $\mathrm{kg} / \mathrm{ha}$ \\
& & & & & & \\
\hline Abies & $0.83 \pm$ & $2.16 \pm$ & $19.10 \pm$ & $49.66 \pm$ & $5.00 \pm$ & $13.10 \pm$ \\
alba & 0.56 & 1.47 & 18.60 & 48.36 & 4.66 & 12.12 \\
Fagus & $1.09 \pm$ & $2.83 \pm$ & $24.90 \pm$ & $64.74 \pm$ & $6.60 \pm$ & $17.11 \pm$ \\
sylvatica & 0.60 & 1.56 & 19.73 & 51.29 & 4.60 & 11.96 \\
Larix & $1.21 \pm$ & $3.15 \pm$ & $12.17 \pm$ & $31.64 \pm$ & $3.70 \pm$ & $9.72 \pm$ \\
decidua & 0.82 & 2.13 & 4.73 & 12.31 & 1.49 & 3.87 \\
Picea & $0.87 \pm$ & $2.18 \pm$ & $9.90 \pm$ & $25.74 \pm$ & $3.00 \pm$ & $7.70 \pm$ \\
abies & 0.37 & 0.97 & 3.02 & 7.86 & 0.63 & 1.63 \\
Quercus & $0.84 \pm$ & $2.18 \pm$ & $34.95 \pm$ & $90.87 \pm$ & $8.70 \pm$ & $22.62 \pm$ \\
petraea & 0.77 & 2.00 & 24.78 & 64.43 & 5.65 & 14.70 \\
a.m. \pm SD & $0.97 \pm$ & $2.52 \pm$ & $20.20 \pm$ & $52.53 \pm$ & $5.40 \pm$ & $14.05 \pm$ \\
& 0.62 & 1.61 & 17.98 & 46.74 & 4.21 & 10.94 \\
\hline
\end{tabular}

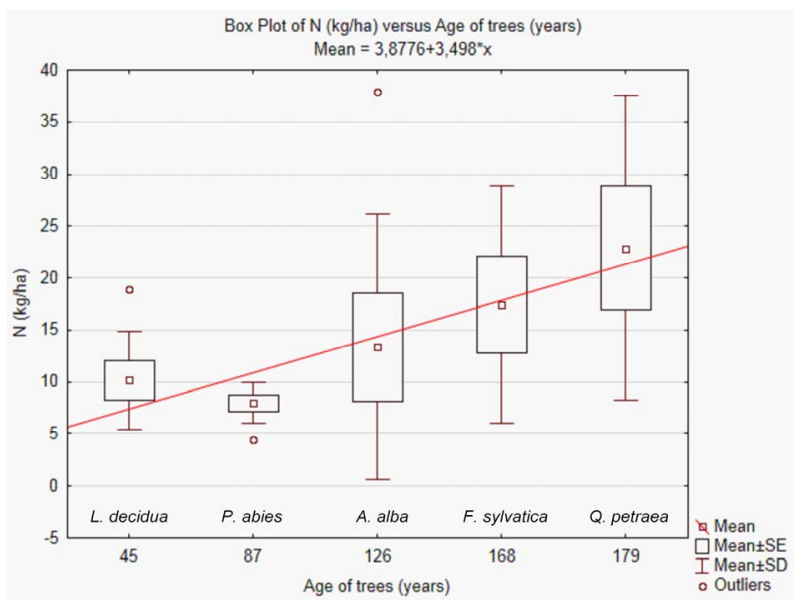

Figure 2. Age of tree stands and total $\mathrm{N}(\mathrm{kg} \mathrm{N} / \mathrm{ha}$ ) contents in upper soils $(0-5 \mathrm{~cm})$. The $\mathrm{N}$ concentrations in the investigated tree stands were measured in 2012. The graph was plotted by use of the software STATISTICA (StatSoft). SE = standard error, $\mathrm{SD}=$ standard deviation (coefficient 1 for $\mathrm{SE}$ and SD). The coefficient for outliers is 1.5.

Table 4. Fragment length of amplified ITS regions and DNA lengths after restriction with Hinf I.

\begin{tabular}{|c|c|c|c|}
\hline & Mycorrhiza species & $\begin{array}{c}\text { ITS-Fragment } \\
{[\mathrm{bp}]}\end{array}$ & $\begin{array}{l}\text { Restriction } \\
\text { bands [bp] }\end{array}$ \\
\hline 1 & Boletus edulis & 900 & $280 / 250$ \\
\hline 2 & Byssocorticium atrovirens & 800 & $420 / 320$ \\
\hline 3 & Cenococcum geophilum & 750 & $420 / 270$ \\
\hline 4 & Cortinarius anomalus & 800 & $380 / 230$ \\
\hline 5 & Cortinarius casimiri & 800 & $380 / 310$ \\
\hline 6 & Cortinarius subsertipes & 700 & $320 / 300$ \\
\hline 7 & Fagirhiza cystidiophora & 750 & $400 / 380$ \\
\hline 8 & $\begin{array}{l}\text { Fagirhiza tubulosa (syn. } \\
\text { Sphaerozone ostiolatum) }\end{array}$ & 850 & $320 / 280$ \\
\hline 9 & Genea hispidula & 800 & $334 / 320$ \\
\hline 10 & $\begin{array}{c}\text { Laccaria amethystina } \\
\text { (syn. Laccaria amethystea) }\end{array}$ & 900 & $420 / 320$ \\
\hline 11 & Lactarius hepaticus & 900 & $400 / 380$ \\
\hline 12 & Lactarius necator & 900 & $450 / 350$ \\
\hline 13 & Lactarius quietus & 900 & $470 / 350$ \\
\hline 14 & Lactarius subdulcis & 900 & $450 / 280$ \\
\hline 15 & Lactarius tabidus & 900 & $420 / 400$ \\
\hline 16 & Melanogaster variegatus & 900 & $400 / 380$ \\
\hline 17 & Paxillus involutus & 850 & $330 / 250$ \\
\hline 18 & Russula ochroleuca & 800 & $280 / 230$ \\
\hline 19 & Scleroderma citrinum & 900 & $350 / 250$ \\
\hline 20 & Thelephora terrestris & 850 & $350 / 250$ \\
\hline 21 & Tomentella stuposa & 800 & $350 / 250$ \\
\hline 21 & Tylopilus felleus & 800 & $350 / 250$ \\
\hline 23 & Xerocomus badius & 800 & $320 / 300$ \\
\hline 24 & Xerocomus chrysenteron & 900 & $450 / 320$ \\
\hline 25 & Xerocomus pruinatus & 900 & $350 / 250$ \\
\hline
\end{tabular}




\subsubsection{ITS-RFLP-Patterns}

The mycorrhizal species with silvery-white to light yellow root tips bearing the fungi Boletus edulis, Xerocomus badius, Xerocomus chrysenteron or Xerocomus pruinatus, are difficult to distinguish by morphological traits. By amplifying the ITS region and restricting it with the restriction enzyme Hinf I these four species can clearly be distinguished [23]. Restriction leads to two DNA bands of different sizes for the four fungi. In case of Xerocomus badius we obtained DNA bands sized 320 and $300 \mathrm{bp}$ (Table 4). For Xerocomus chrysenteron fragment lengths of 450 and $320 \mathrm{bp}$ resulted and in case of Xerocomus pruinatus one DNA band of $350 \mathrm{bp}$ and one of $250 \mathrm{bp}$ were obtained. The restriction pattern of Boletus edulis resembles that of Xerocomus badius; however the DNA bands have a length of 280 and $250 \mathrm{bp}$ (Table 4).

The ITS band lengths of the 25 mycorrhizal species investigated are presented in Table 4 together with the restriction bands obtained from these.

ITS fragments using the primer pair ITS1/ITS4b ranged from about 700 to $900 \mathrm{bp}$. Restriction of amplified ITS bands resulted in two DNA fragments with sizes between about 250 to $470 \mathrm{bp}$.

\subsubsection{Sequenced ITS-Fragments}

Amplified ITS-fragments were sequenced and the resulting sequences were compared with those listed in the public sequence-databases NCBI and UNITE, using the same settings for BLAST (Table 5). The investigated sequences were submitted to GenBank (NCBI).

\subsection{Composition of Mycorrhizal Communities}

\subsubsection{Diversity of Ectomycorrhizal Species on Five Different Forest Tree Species}

\subsubsection{Total Diversity}

On the five different tree species growing in the Taunus Mountains, a total of 25 different ectomycorrhizal fungi have been identified to the species level using RFLP-analysis and sequencing the ITS region (Table 4 and Table 5). Of these, three species belong to the genus Xerocomus. On fine roots infected with the genus Xerocomus we identified another 22 mycorrhizal species (Table 5). Further seven ectomycorrhizal fungi (Cortinarius spp., Lactarius spp., Melanogaster spp., Paxillus spp., Piloderma spp., Tomentella spp., Xerocomus spp.) could only be identified to genus level, so that in total 32 different mycorrhizal fungi could be determined on the five different tree species.

The most frequent species in our study were Boletus edulis (31 individuals), Lactarius subdulcis (22 ind.), Paxillus involutus (51 ind.) and Russula ochroleuca (41 ind.) (Table 6).
Table 5. Mycorrhizal species identified by their ITS-sequences.

\begin{tabular}{|c|c|c|c|c|c|}
\hline $\begin{array}{c}\text { Name of best } \\
\text { BLAST match }\end{array}$ & GenBank & UNITE & $\begin{array}{c}\text { Scores } \\
\text { (bits) }\end{array}$ & e-value & $\begin{array}{c}\% \\
\text { Similarity }\end{array}$ \\
\hline $\begin{array}{r}\text { Boletus } \\
\text { edulis }\end{array}$ & & UDB001522 & 21348 & 0.0 & 99 \\
\hline $\begin{array}{r}\text { Byssocorticium } \\
\text { atrovirens }\end{array}$ & & UDB000075 & 51336 & 0.0 & 99 \\
\hline $\begin{array}{l}\text { Cortinarius } \\
\text { anomalus }\end{array}$ & & UDB000056 & 61336 & 0.0 & 99 \\
\hline $\begin{array}{c}\text { Cortinarius } \\
\text { casimiri }\end{array}$ & HQ604714.1 & & 1251 & 0.0 & 99 \\
\hline $\begin{array}{l}\text { Cortinarius } \\
\text { subsertipes }\end{array}$ & AY669679.1 & & 1201 & 0.0 & 99 \\
\hline $\begin{array}{r}\text { Cenococcum } \\
\text { geophilum }\end{array}$ & & UDB003456 & 61306 & 0.0 & 99 \\
\hline $\begin{array}{c}\text { Fagirhiza } \\
\text { cystidiophora }\end{array}$ & & UDB005056 & 51336 & 0.0 & 99 \\
\hline $\begin{array}{r}\text { Fagirhiza } \\
\text { tubulosa }\end{array}$ & & UDB000856 & 51456 & 0.0 & 99 \\
\hline $\begin{array}{l}\text { Genea } \\
\text { hispidula }\end{array}$ & & UDB001408 & 31148 & 0.0 & 100 \\
\hline $\begin{array}{l}\text { Laccaria } \\
\text { amethystina }\end{array}$ & & UDB000006 & 1342 & 0.0 & 99 \\
\hline $\begin{array}{l}\text { Lactarius } \\
\text { hepaticus }\end{array}$ & & UDB000861 & 1162 & 0.0 & 99 \\
\hline $\begin{array}{l}\text { Lactarius } \\
\text { necator }\end{array}$ & & UDB003215 & 51352 & 0.0 & 99 \\
\hline $\begin{array}{r}\text { Lactarius } \\
\text { quietus }\end{array}$ & & UDB000889 & 1283 & 0.0 & 99 \\
\hline $\begin{array}{l}\text { Lactarius } \\
\text { subdulcis }\end{array}$ & & UDB000331 & 1225 & 0.0 & 100 \\
\hline $\begin{array}{r}\text { Lactarius } \\
\text { tabidus }\end{array}$ & & UDB000385 & 1251 & 0.0 & 99 \\
\hline $\begin{array}{c}\text { Melanogaster } \\
\text { variegatus }\end{array}$ & AJ555511.1 & & 1225 & 0.0 & 97 \\
\hline $\begin{array}{l}\text { Paxillus } \\
\text { involutus }\end{array}$ & & UDB001205 & 51271 & 0.0 & 99 \\
\hline $\begin{array}{c}\text { Russula } \\
\text { ochroleuca }\end{array}$ & & UDB000295 & 1279 & 0.0 & 99 \\
\hline $\begin{array}{c}\text { Scleroderma } \\
\text { citrinum }\end{array}$ & HM189957.1 & & 1141 & 0.0 & 100 \\
\hline $\begin{array}{r}\text { Thelephora } \\
\text { terrestris }\end{array}$ & & UDB000255 & 1156 & 0.0 & 100 \\
\hline $\begin{array}{r}\text { Tomentella } \\
\text { stuposa }\end{array}$ & & UDB003314 & 1150 & 0.0 & 99 \\
\hline $\begin{array}{r}\text { Tylopilus } \\
\text { felleus }\end{array}$ & & UDB000680 & 1067 & 0.0 & 98 \\
\hline $\begin{array}{c}\text { Xerocomus } \\
\text { badius }\end{array}$ & & UDB000437 & 1366 & 0.0 & 99 \\
\hline $\begin{array}{l}\text { Xerocomus } \\
\text { chrysenteron }\end{array}$ & & UDB001403 & 1465 & 0.0 & 99 \\
\hline $\begin{array}{r}\text { Xerocomus } \\
\text { pruinatus }\end{array}$ & & UDB000049 & 1576 & 0.0 & 100 \\
\hline
\end{tabular}

Accession numbers of ITS sequences submitted to GenBank are listed in the appendix (Table A1).

According to their relative occurrences ectomycorrhizal species were classified into six dominance classes [33]: 1) numerous $(100 \%-32 \%), 2)$ frequent $(31.99 \%-$ $10 \%), 3)$ often $(9.99 \%-3.2 \%), 4)$ occasional $(3.1 \%$ $1.0 \%), 5)$ scattered $(0.99 \%-0.32 \%)$ and 6$)$ rare $(0.31 \%$ $0 \%$ ). The corresponding frequencies are listed in Table 6. 
Table 6. Absolute and relative frequencies of ectomycorrhizal fungi identified on five different tree species.

\begin{tabular}{|c|c|c|c|c|}
\hline & \multirow[t]{2}{*}{ Mycorrhizal species } & \multicolumn{2}{|c|}{ Frequency } & \multirow[t]{2}{*}{ Classification } \\
\hline & & Absolute & Relative (\%) & \\
\hline 1 & $\begin{array}{l}\text { Paxillus } \\
\text { involutus }\end{array}$ & 51 & 15.3 & frequent \\
\hline 2 & $\begin{array}{l}\text { Russula } \\
\text { ochroleuca }\end{array}$ & 41 & 12.3 & frequent \\
\hline 3 & $\begin{array}{l}\text { Boletus } \\
\text { edulis }\end{array}$ & 31 & 9.3 & often \\
\hline 4 & Lactarius spp. & 24 & 7.2 & often \\
\hline 5 & $\begin{array}{l}\text { Lactarius } \\
\text { subdulcis }\end{array}$ & 22 & 6.6 & often \\
\hline 6 & $\begin{array}{l}\text { Laccaria } \\
\text { amethystina }\end{array}$ & 20 & 6.0 & often \\
\hline 7 & $\begin{array}{l}\text { Paxillus } \\
\text { spp. }\end{array}$ & 16 & 4.8 & often \\
\hline 8 & $\begin{array}{l}\text { Scleroderma } \\
\text { citrinum }\end{array}$ & 14 & 4.2 & often \\
\hline 9 & $\begin{array}{l}\text { Cortinarius } \\
\text { spp. }\end{array}$ & 13 & 3.9 & often \\
\hline 10 & $\begin{array}{l}\text { Fagirhiza } \\
\text { tubulosa }\end{array}$ & 13 & 3.9 & often \\
\hline 11 & $\begin{array}{c}\text { Melanogaster } \\
\text { variegatus }\end{array}$ & 12 & 3.6 & often \\
\hline 12 & $\begin{array}{l}\text { Cortinarius } \\
\text { casimiri }\end{array}$ & 11 & 3.3 & often \\
\hline 13 & $\begin{array}{c}\text { Fagirhiza } \\
\text { cystidiophora }\end{array}$ & 11 & 3.3 & often \\
\hline 14 & $\begin{array}{l}\text { Cenococcum } \\
\text { geophilum }\end{array}$ & 9 & 2.7 & occasional \\
\hline 15 & $\begin{array}{l}\text { Tomentella } \\
\text { stuposa }\end{array}$ & 9 & 2.7 & occasional \\
\hline 16 & $\begin{array}{l}\text { Byssocorticium } \\
\text { atrovirens }\end{array}$ & 7 & 2.1 & occasional \\
\hline 17 & Genea hispidula & 7 & 2.1 & occasional \\
\hline 18 & $\begin{array}{l}\text { Lactarius } \\
\text { hepaticus }\end{array}$ & 6 & 1.8 & occasional \\
\hline 19 & Lactarius tabidus & 4 & 1.2 & occasional \\
\hline 20 & $\begin{array}{l}\text { Thelephora } \\
\text { terrestris }\end{array}$ & 3 & 0.9 & scattered \\
\hline 21 & $\begin{array}{l}\text { Tomentella } \\
\text { spp. }\end{array}$ & 3 & 0.9 & scattered \\
\hline 22 & $\begin{array}{l}\text { Cortinarius } \\
\text { anomalus }\end{array}$ & 1 & 0.3 & rare \\
\hline 23 & $\begin{array}{l}\text { Cortinarius } \\
\text { subsertipes }\end{array}$ & 1 & 0.3 & rare \\
\hline 24 & $\begin{array}{l}\text { Lactarius } \\
\text { necator }\end{array}$ & 1 & 0.3 & rare \\
\hline 25 & $\begin{array}{l}\text { Lactarius } \\
\text { quietus }\end{array}$ & 1 & 0.3 & rare \\
\hline 26 & $\begin{array}{l}\text { Melanogaster } \\
\text { spp. }\end{array}$ & 1 & 0.3 & rare \\
\hline 27 & $\begin{array}{l}\text { Piloderma } \\
\text { spp. }\end{array}$ & 1 & 0.3 & rare \\
\hline 28 & $\begin{array}{l}\text { Tylopilus } \\
\text { felleus }\end{array}$ & 1 & 0.3 & rare \\
\hline
\end{tabular}

*Relative frequencies are related to a total of 334 mycorrhizal samples. The listed genera and species were obtained in a specific search for mycorrhizae of the genus Xerocomus.

\subsubsection{Mycorrhizal Diversity by Site}

Some ectomycorrhizal species were found on each of the five investigated tree species such as Cortinarius casimiri, Laccaria amethystina, Lactarius subdulcis, Paxillus involutus and Russula ochroleuca (Table 7). Other mycorrhizal species like Cortinarius subsertipes, Genea hispidula, Lactarius quietus, Tylopilus felleus and a to the genus level identified Melanogaster type, occurred exclusively on the two deciduous tree species European beech and Sessile oak (Table 7). The three coniferous species Silver fir, European larch and Norway spruce were specifically infected by Cortinarius anomalus, Lactarius necator and an unidentified Piloderma and Tomentella species. The fungi Cenococcum geophilum, Fagirhiza cystidiophora, Fagirhiza tubulosa and a Cortinarius type did not infect Silver fir but European beech, sessile oak, European larch and Norway spruce (Table 7).

On all examined five tree species the five mycorrhizal fungi Cortinarius casimiri, Laccaria amethystina, Lactarius subdulcis, Paxillus involutus and Russula ochroleuca were found. They made together 145 out of 334 mycorrhizal findings, i.e. 43\% (Table 7).

On the two deciduous tree species we identified Cortinarius subsertipes, Genea hispidula, Lactarius quietus, Tylopilus felleus and Melanogaster spp. They made 11 out of 334 findings, i.e. $3.3 \%$. Of these the first four were found on Quercus petraea while Genea hispidula and Melanogaster spp. were observed exclusively on F. sylvatica.

The four species found exclusively on conifers showed an extremely rare occurrence (1.8\%). Lactarius necator was identified only on Picea abies and Cortinarius anomalus only on Abies alba.

Eleven identified ectomycorrhizal species and three genera occurred on the broad-leafed trees as well as on conifers investigated. They made together $52 \%$ of all mycorrhizal findings.

Rarity and commonness of mycorrhizal species in the forest stands investigated in the Taunus Mountains were quantified by calculating the diversity indexes Shannon index $\left(\mathrm{H}^{\prime}\right)$, maximum diversity index (maximum value of the Shannon index, $\mathrm{H}_{\max }$ ) and Shannon evenness (E). The corresponding values are indicated in Table 8.

The slightest diversity index $\left(\mathrm{H}^{\prime}=2.2515\right)$ was calculated for mycorrhizae on European larch, the highest index was calculated for European beech $\left(H^{\prime}=2.6945\right)$. Mycorrhizae on the three conifer species Larix decidua, Abies alba and Picea abies showed a lower mycorrhizal diversity than those on the two deciduous species Fagus sylvatica and Quercus petraea. European beech and sessile oak are native trees in the Taunus area, while the conifers were planted about one hundred years ago. Therefore, not all of the native occurring mycorrhizae seem to have the capability to form a symbiosis with the non-native trees.

Looking at the surveyed tree species separately the differences in the mycorrhizal species spectrum are more 
Table 7. Distribution and frequency of ectomycorrhizal species among five different tree species growing on monocultural forests in the Taunus Mts.

\begin{tabular}{|c|c|c|c|c|c|c|}
\hline Mycorrhizal species & A. alba & F. sylvatica & L. decidua & P. abies & Q. petraea & $\sum$ \\
\hline \multicolumn{7}{|c|}{ ubiquitous species found in all investigated stands } \\
\hline Cortinarius casimiri & $1(2.2 \%)^{*}$ & $3(2.7 \%)$ & $1(1.6 \%)$ & $3(4.2 \%)$ & $3(7.0 \%)$ & 11 \\
\hline Laccaria amethystina & $2(4.3 \%)$ & $7(6.4 \%)$ & $9(14.3 \%)$ & $1(1.4 \%)$ & $1(2.3 \%)$ & 20 \\
\hline Lactarius subdulcis & $2(4.3 \%)$ & $5(4.5 \%)$ & $6(9.5 \%)$ & $6(8.3 \%)$ & $3(7.0 \%)$ & 22 \\
\hline Paxillus involutus & $4(8.7 \%)$ & $13(11.8 \%)$ & $15(23.8 \%)$ & $14(19.4 \%)$ & $5(11.6 \%)$ & 51 \\
\hline \multirow{2}{*}{ Russula ochroleuca } & $4(8.7 \%)$ & $10(9.1 \%)$ & $12(19.0 \%)$ & $13(18.1 \%)$ & $2(4.7 \%)$ & 41 \\
\hline & & & & & \multicolumn{2}{|c|}{$\sum 145$} \\
\hline \multicolumn{7}{|c|}{ exclusively on deciduous trees } \\
\hline Cortinarius subsertipes & & & & & $1(2.3 \%)$ & 1 \\
\hline Genea hispidula & & $5(4.5 \%)$ & & & $2(4.7 \%)$ & 7 \\
\hline Lactarius quietus & & & & & $1(2.3 \%)$ & 1 \\
\hline Tylopilus felleus & & & & & $1(2.3 \%)$ & 1 \\
\hline \multirow[t]{2}{*}{ Melanogaster spp. } & & $1(0.9 \%)$ & & & & 1 \\
\hline & & & & & \multicolumn{2}{|c|}{$\sum 11$} \\
\hline \multicolumn{7}{|c|}{ exclusively on coniferous trees } \\
\hline Cortinarius anomalus & $1(2.2 \%)$ & & & & & 1 \\
\hline Lactarius necator & & & & $1(1.4 \%)$ & & 1 \\
\hline Piloderma spp. & $1(2.2 \%)$ & & & & & 1 \\
\hline \multirow[t]{2}{*}{ Tomentella spp. } & $1(2.2 \%)$ & & $2(3.2 \%)$ & & & 3 \\
\hline & & & & & \multicolumn{2}{|l|}{$\sum 5$} \\
\hline \multicolumn{7}{|c|}{ common species } \\
\hline Boletus edulis & $8(17.4 \%)$ & $19(17.3 \%)$ & & $4(5.6 \%)$ & & 31 \\
\hline Byssocorticium atrovirens & $1(2.2 \%)$ & $4(3.6 \%)$ & & $1(1.4 \%)$ & $1(2.3 \%)$ & 7 \\
\hline Cenococcum geophilum & & $3(2.7 \%)$ & $1(1.6 \%)$ & $3(4.2 \%)$ & $2(4.7 \%)$ & 9 \\
\hline Fagirhiza cystidiophora & & $3(2.7 \%)$ & $3(4.8 \%)$ & $2(2.8 \%)$ & $3(7.0 \%)$ & 11 \\
\hline Fagirhiza tubulosa & & $2(1.8 \%)$ & $3(4.8 \%)$ & $2(2.8 \%)$ & $6(14.0 \%)$ & 13 \\
\hline Lactarius hepaticus & & $3(2.7 \%)$ & $3(4.8 \%)$ & & & 6 \\
\hline Lactarius tabidus & & $1(0.9 \%)$ & $2(3.2 \%)$ & & $1(2.3 \%)$ & 4 \\
\hline Melanogaster variegatus & $2(4.3 \%)$ & $4(3.6 \%)$ & & $4(5.6 \%)$ & $2(4.7 \%)$ & 12 \\
\hline Scleroderma citrinum & $7(15.2 \%)$ & $3(2.7 \%)$ & & $4(5.6 \%)$ & & 14 \\
\hline Thelephora terrestris & $1(2.2 \%)$ & & $1(1.6 \%)$ & & $1(2.3 \%)$ & 3 \\
\hline Tomentella stuposa & $6(13.0 \%)$ & $3(2.7 \%)$ & & & & 9 \\
\hline Cortinarius spp. & & $5(4.5 \%)$ & $1(1.6 \%)$ & $5(6.9 \%)$ & $2(4.7 \%)$ & 13 \\
\hline Lactarius spp. & & $14(12.7 \%)$ & & $4(5.6 \%)$ & $6(14.0 \%)$ & 24 \\
\hline Paxillus spp. & $5(10.9 \%)$ & $2(1.8 \%)$ & $4(6.3 \%)$ & $5(6.9 \%)$ & & 16 \\
\hline$\sum^{1}$ & 15 & 20 & 14 & 16 & 18 & \\
\hline$\Sigma^{2}$ & 12 & 16 & 11 & 13 & 16 & \\
\hline$\Sigma^{3}$ & 46 & 110 & 63 & 72 & 43 & 334 \\
\hline
\end{tabular}

*Brackets denote relative frequencies related to the total number of mycorrhizal individuals identified per tree species; $\sum^{1}$ : Mycorrhizal species and genera per tree species; $\Sigma^{2}$ : Mycorrhizal species; $\Sigma^{3}$ : Total number of mycorrhizal individuals per tree species. 
Table 8. Biodiversity-indexes of mycorrhizae examined in five tree stands in the Taunus Mountains.

\begin{tabular}{|c|c|c|c|c|c|}
\hline & A. alba & F. sylvatica & L. decidua & P. abies & Q. petraea \\
\hline $\mathbf{H}^{\prime}$ & 2.4307 & 2.6945 & 2.2515 & 2.4894 & 2.6829 \\
\hline $\mathbf{H}_{\max }$ & 2.7080 & 2.9957 & 2.6390 & 2.7725 & 2.8903 \\
\hline $\mathbf{E}$ & 0.8975 & 0.8994 & 0.8531 & 0.8978 & 0.9282 \\
\hline $\begin{array}{c}\sum \text { (mycorrhizal } \\
\text { individuals) }\end{array}$ & 46 & 110 & 63 & 72 & 43 \\
\hline $\begin{array}{c}\sum \begin{array}{c}\text { (mycorrhizal } \\
\text { species) }\end{array} \\
\text { t }\end{array}$ & 15 & 20 & 14 & 16 & 18 \\
\hline
\end{tabular}

pronounced. We focus here on those species with relative frequencies $\geq 3.2 \%$, classified as numerous, frequent and often.

\subsubsection{Abies alba}

On 42 fir trees 46 mycorrhizal individuals were collected. In these samples 15 different ectomycorrhizal genera and species were identified. As frequent (31.99\% $10 \%$ ) were classified Boletus edulis, Scleroderma citrinum, Tomentella stuposa and as often (9.99\% - 3.2\%) Paxillus spp., Paxillus involutus, Russula ochroleuca, Laccaria amethystina, Lactarius subdulcis and Melanogaster variegatus. Species with relative frequencies $\leq$ $3.2 \%$ are listed in Table 7.

On the five tree species investigated in this study a total of 22 ectomycorrhizal species were identified. Of these 12 species (55\%) were determined at A. alba (Table 7). Seven species occurred at lower frequencies while 5 occurred on higher frequencies on Silver fir in comparison to the remaining four tree species (Figure 3). Cortinarius anomalus was found exclusively on Abies alba. Scleroderma citrinum and Tylopilus felleus were found three times and more often on this tree species than on the remaining four tree species (Figure 3).

Cremer studied [34] the occurrence and frequency of ectomycorrhizal fungi on Silver fir growing in the northern Black Forest (Table 9). The three species Laccaria amethystina (7.1\%), Russula ochroleuca (11.9\%) and Tomentella stuposa (24.2\%) which she observed were also found during our investigations (Table 8). Comandini and coworkers [35] studied the occurrence of mycorrhizal fungi on Silver fir growing in Central Italy. They did not find the mycorrhizal species named in Figure 3, except for Byssocorticium atrovirens and Laccaria amethystina. However, they identified Phellodon niger, Tricholoma bufonium, Lactarius salmonicolor and Lactarius scrobiculatus which we did not find on Abies alba growing in the Taunus region.

\subsubsection{Fagus sylvatica}

On 189 sampled European beech 110 mycorrhizal samples were collected comprising 20 different ectomy- corrhizal fungi. This is the highest diversity which we observed on the five tree species investigated here. As frequent $(31.99 \%$ - 10\%) were classified Boletus edulis, Lactarius spp. and Paxillus involutus (Table 7). Often (9.99\% - 3.2\%) appeared Russula ochroleuca, Laccaria amethystina, Cortinarius spp., Genea hispidula, Lactarius subdulcis, Byssocorticium atrovirens and Melanogaster variegatus (Table 7).

Of the 22 ectomycorrhizal species identified on the 5 tree species, we determined 16 species $(73 \%)$ on F. sylvatica. Six fungal species were not found on this tree species (Figure 4, Table 7). Boletus edulis, Byssocorticium atrovirens, Genea hispidula and Lactarius hepaticcus were found three times and more often on European beech than on the remaining four tree species (Figure 4).

During her investigations on the mycorrhizal species richness and host preferences on European beech growing in the National Park Hainich in Thuringa in central Europe, Lang and coworkers [36] determined as frequent occurring species Clavulina cristata (14.2\%), Lactarius subdulcis* (12.7\%) and Tomentella sublilacina (11.1\%) (cf. Table 8). According to our nomenclature they found Cenococcum geophilum* (9.6\%), Russula delica (4.9\%) and Russula ochroleuca* $(5.5 \%)$ often. The mycorrhizae marked with an asterisk were also found in the present study.

The incidence of ectomycorrhizae infecting European beech growing in two wooded areas on the south slopes of the Taunus Mountains was studied before by Schauf and Rothe [37] (Table 9). They found the following fungal species Byssocorticium atrovirens* (5\% and 15\%), Cenococcum geophilum* (75\% and 70\%), Cortinarius spp. (35 and 10\%), Elaphomyces muricatus (20\% and $0 \%$ ), Fagirhiza arachnoidea (0\% and $10 \%)$, Fagirhiza cystidiosphora* (55\% and 0\%), Fagirhiza fusca (5\% and 5\%), Fagirhiza spinulosa (0 and 5\%), Genea hispidula*

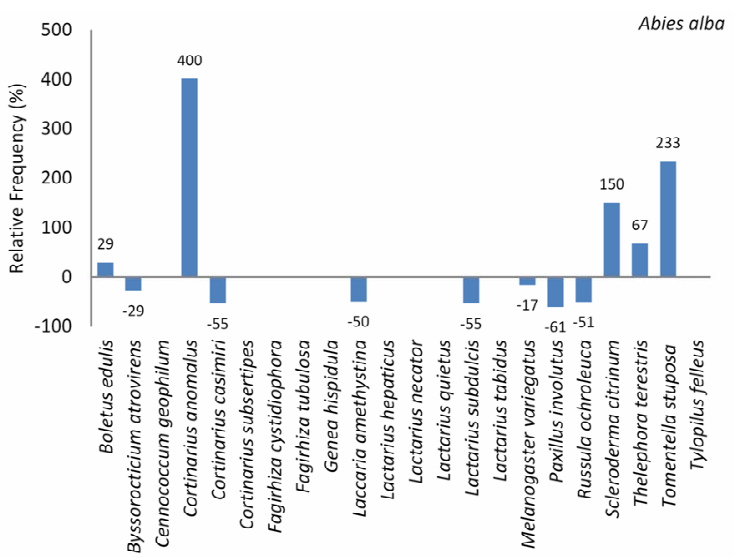

Figure 3. Per cent deviation from the mean frequencies of individuals of the presented fungal species, identified on the five investigated tree species. The arithmetic mean resulted from the number of individuals per mycorrhizal species divided by 5 , the number of tree species. 


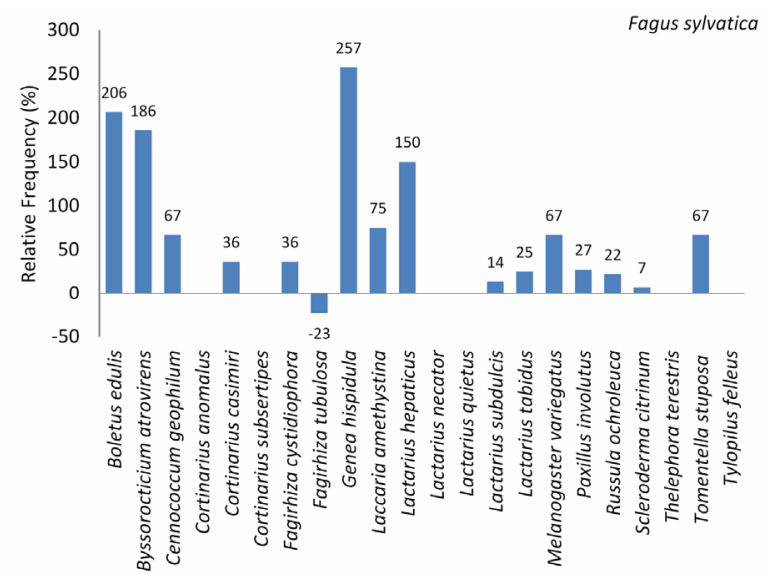

Figure 4. Per cent deviation from the mean frequencies of individuals of the presented fungal species, identified on the five investigated tree species. The arithmetic mean resulted from the number of individuals per mycorrhizal species divided by 5 , the number of tree species.

(70\% and 60\%), Laccaria amethystina* (60\% and $0 \%)$, Laccaria spp. (20\% and $85 \%)$, Russula fellea (10\% and $0 \%$ ), Russula illota (30\% and 10\%), Russula mairei (10\% and $0 \%)$, Russula ochroleuca* (5\% and $65 \%)$, Sphaerozone ostiolatum (syn: Fagirhiza tubulosa)* $(70 \%$ and 5\%) and Xerocomus chrysenteron* (40\% and 65\%). The eight types marked with an asterisk were also found in the present study.

\subsubsection{Larix decidua}

On 115 European larch trees a total of 63 mycorrhizal samples were collected comprising 14 mycorrhizal genera and species. Paxillus involutus, Russula ochroleuca and Laccaria amethystina appeared frequent $(31.99 \%$ 10\%) (Table 7). Often (9.99\% - 3.2\%) occurred Fagirhiza cystidiophora, Fagirhiza tubulosa, Lactarius hepaticus, Lactarius subdulcis, Lactarius tabidus, Paxillus spp. and Tomentella spp. Mycorrhizal species with lower relative frequencies than $3.2 \%$ are shown in Table 7.

Of the 22 ectomycorrhizal species identified on the five tree species 11 species (50\%) were determined on $L$. decidua. Eleven fungal species were not found on this tree species in comparison to the remaining four species (Figure 5, Table 7). Lactarius hepaticus and Lactarius tabidus were found three times more often on European larch than on the remaining four tree species (Figure 5).

The ectomycorrhizal status of European larch (Larix decidua) seedlings was also investigated in bare-root forest nurseries in northern Poland [38]. The authors identified the following species: Suillus grevillei (32.9\%), Wilcoxina mikolae (56.4\%) (cf. Table 9), Tuber oligospermum (1.7\%), Tuber borchii (1.7\%), Geophora sf. cervina (5.8\%), Tirmania nivea (1.4\%), and Cazia flexiascus $(0.4 \%)$. None of these species were found on the studied European larch growing on the Taunus Moun- tains.

\subsubsection{Picea abies}

Seventy-two mycorrhizae were collected on 190 spruce trees. These comprised 16 mycorrhizal genera and species. A relatively high number of individuals resulted for Paxillus involutus (19.4\%) and Russula ochroleuca (18.1\%). These species were therefore classified as frequent. The following species and genera occurred often (9.99\% - 3.2\%): Boletus edulis, Cenococcum geophilum, Cortinarius casimiri, Cortinarius spp., Lactarius spp., Lactarius subdulcis, Melanogaster variegatus, Paxillus spp. and Scleroderma citrinum. All other species were found occasional, i.e. with frequencies lower than 3.2\% (Table 7).

A total of 22 ectomycorrhizal species were identified on the five tree species. Of these 13 species (59\%) were determined on $P$. abies. Nine fungal species were not found on this tree species (Figure 6, Table 7). Lactarius necator was found exclusively on Norway spruce (Figure 6).

In a Picea abies stand near the city of Augsburg, southern Germany, the following fungi were observed frequently: Piceirhiza nigra (14.7\%) and Russula ochroleuca (15.3\%) (cf. Table 9). The species Piceirhiza conspicula $(6.7 \%)$, Tuber puberulum $(6.9 \%)$ and Xerocomus badius (6\%) were often observed [39]. The species Russula ochroleuca was also identified in our study.

\subsubsection{Quercus petraea}

On 36 sessile oaks we collected 43 mycorrhizal samples, 18 different mycorrhizal genera and species. Sessile oak had the second high mycorrhizal species range of the five investigated tree species. On Sessile oak frequent

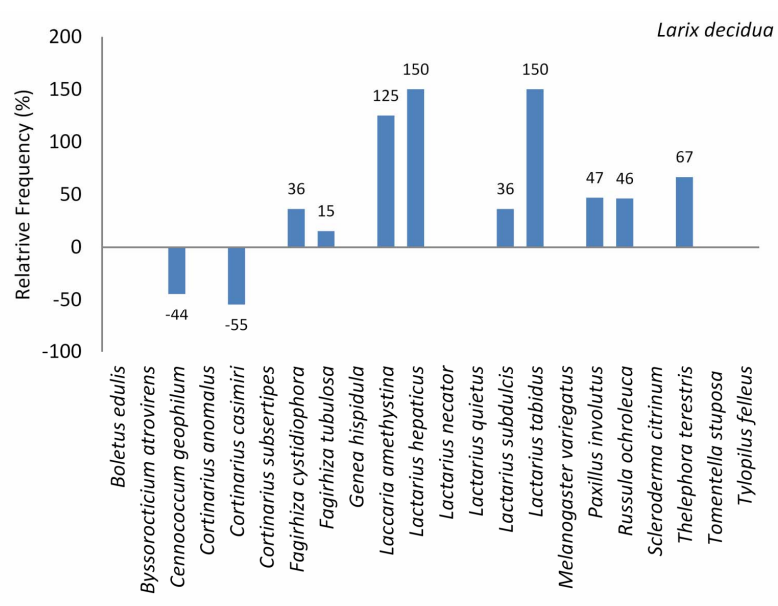

Figure 5. Deviation of the relative frequency of the individuals of mycorrhizal species on $L$. decidua from the mean frequency set to $100 \%$. The arithmetic mean resulted from the number of individuals per mycorrhizal species divided by the number of tree species. 


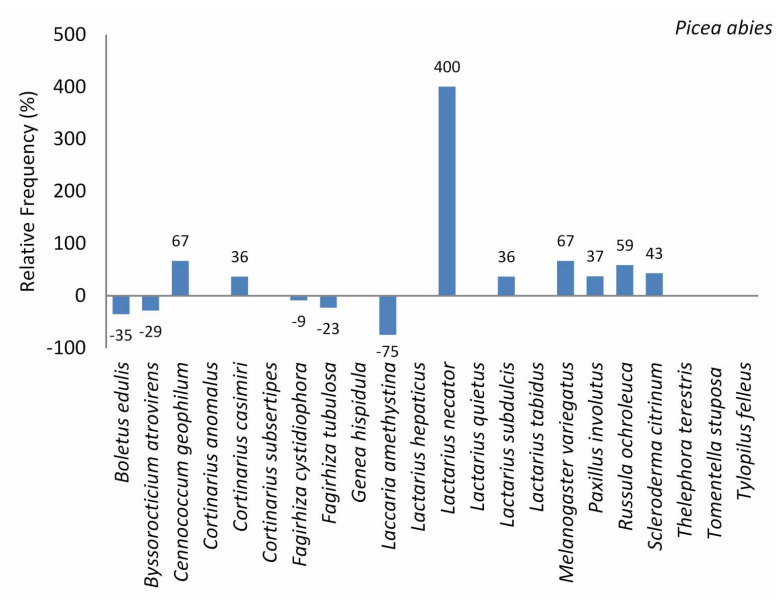

Figure 6. Deviation of the relative frequency of mycorrhizal individuals of species on $P$. abies from the mean frequency set to $100 \%$. The arithmetic mean resulted from the number of individuals per mycorrhizal species divided by the number of tree species.

(31.99\% - 10\%) occurring mycorhizzal genera and species were: Fagirhiza tubulosa, Lactarius spp. and Paxillus involutus (Table 7). Mycorrhizae classified as often occurring $(9.99 \%-3.2 \%)$ were Cenococcum geophilum, Cortinarius casimiri, Cortinarius spp., Fagirhiza cystidiophora, Genea hispidula, Lactarius subdulcis, Melanogaster variegatus and Russula ochroleuca. Further seven mycorrhizal species were classified as occasional because of abundances between 3.1\% - 1.0\% (Table 7).

Of the 22 ectomycorrhizal species identified on the five tree species 16 species (73\%) were determined on $Q$. petraea. Six fungal species were not found on this tree species (Figure 7, Table 7). Cortinarius subsertipes, Lactarius quietus and Tylopilus felleus were exclusively found on Quercus petraea (Figure 7).

In her study on ectomycorrhizae of sessile oak in the Palatinate Forest in the Southwest of Germany Wilson [40] identified 65 ectomycorrhizal fungal species. Ten of these species were also found in the present study: Byssocorticium atrovirens, Cenococcum geophilum, Fagirhiza cystidiophora, Fagirhiza tubulosa, Genea hispidula, Laccaria amethystina, Lactarius subdulcis, Lactarius quietus, Paxillus involutus and Russula ochroleuca (Table 9).

In the east of Germany, near the city of Potsdam, Sammler studied the mycorrhizal frequencies on Quercus robur and Quercus petraea [41]. He determined altogether 73 mycorrhizal species (cf. Table 9) of which 62 species were found on Sessile oak. Due to the numerous fungal species the comparison with our data is limited to frequent and often species: The most abundant species with high relative frequencies were Amanita citrine (29\%), Cortinarius torvus (24\%), Laccaria amethystina* (17\%), Lactarius quietus* (23\%), Lactarius vellereus

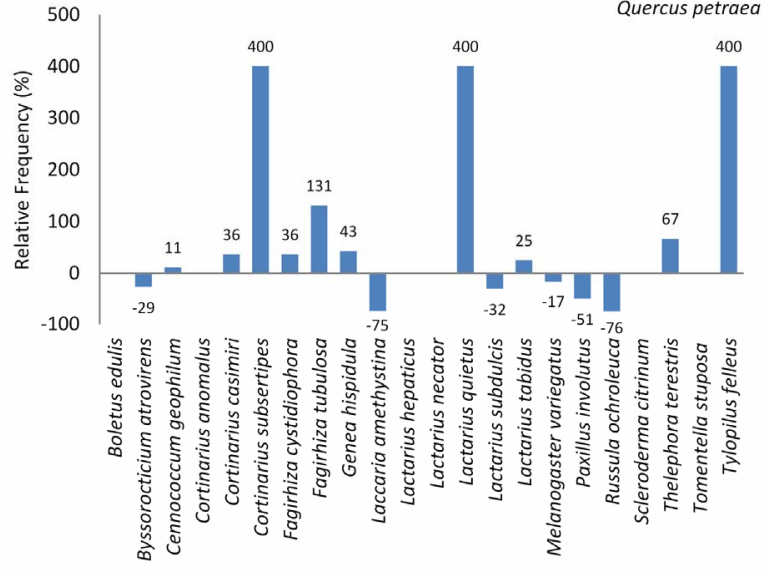

Figure 7. Deviation of the relative frequency of mycorrhizal individuals of species on $Q$. petraea from the mean frequency set to $100 \%$. The arithmetic mean resulted from the number of individuals per mycorrhizal species divided by the number of tree species.

(12\%), Paxillus involutus* (21\%), Rhodocollybia butyracea (22\%), Russula emetica (14\%), Russula fragilis (12\%), Russula graveolens (12\%) and Tricholoma sulphureum (10\%). According to Engelmann [30] they were classified as frequent species. Often found species on Sessile oak were: Amanita fulva (10\%), Amanita pantherina (8\%), Amanita rubescens (11\%), Boletus edulis* $(10 \%)$, Cantharellus cibarius (7\%), Cortinarius hinnuleus (6\%), Cortinarius saniosus (4\%), Cortinarius trivialis (4\%), Hebeloma crustuliniforme (6\%), Laccaria laccata (4\%), Lactarius camphoratus (10\%), Lactarius chrysorrheus (10\%), Russula amoenolens (5\%), Russula ochroleuca* (4\%), Scleroderma areolatum (7\%) and Scleroderma citrinum* (9\%). Mycorrhizal species marked with an asterisk were also found in our study.

\section{DISCUSSION}

Investigations on the occurrence of mycorrhizal species and their frequencies in German forests were performed on European beech [36,37], oak [40,41], Norway spruce [39] and Silver fir [34]. Corresponding investigations on European larch growing in Germany were not published so far. The most often investigated tree species in this context is European beech.

With respect to the total number of different mycorrhizal species identified on various forest trees in Germany the following results were obtained. At the Taunus Mountains (this study) and at the Black Forest [34] together 17 different mycorrhizal species were identified on Abies alba. On Fagus sylvatica investigated at the National Park Hainich in Thuringia [36], the Taunus Mountains [37] and this study 47 different mycorrhizal species were observed. On Larix decidua growing in the Taunus Mountains (this study) 22 different mycorrhizal species 
Table 9. Mycorrhizal fungi investigated at various forest stands in Europe.

\begin{tabular}{|c|c|c|c|c|c|c|c|}
\hline Study site & Soil & pH & Tips & Myc & Most freq. species & Tree & Authors \\
\hline $\begin{array}{l}\text { Northern Black Forest } \\
\text { "Bannwald Grosse } \\
\text { Tannen", "Sauriss" } \\
\text { "Eyachtal", Germany }\end{array}$ & middle red sandstone & $\mathrm{ns}^{*}$ & 753 & 33 & $\begin{array}{c}\text { Tomentella stuposa, } \\
\text { Cenococcum geophillum, } \\
\text { Russula ochroleuca, Lactarius } \\
\text { spp. }\end{array}$ & A. alba & $\begin{array}{c}\text { Cremer, } 2009 \\
{[34]}\end{array}$ \\
\hline $\begin{array}{c}\text { Gran Sasso-Laga National } \\
\text { Park Central Italy }\end{array}$ & Limestone & ns & ns & 25 & Laccaria amethystina & A. alba & $\begin{array}{c}\text { Comandini, et al., } \\
1998 \\
{[35]}\end{array}$ \\
\hline $\begin{array}{c}\text { "Höglwald" near } \\
\text { Augsburg, Bavaria, } \\
\text { Germany }\end{array}$ & $\begin{array}{l}\text { parabrown earth derived } \\
\text { from pleistocene Loess } \\
\text { and sand deposits }\end{array}$ & 3.75 & ns & 14 & $\begin{array}{c}\text { Piceirhiza nigra, Russula } \\
\text { ochroleuca, Tylospora spp. }\end{array}$ & P. abies & $\begin{array}{c}\text { Qian, et al., } 1998 \\
{[39]}\end{array}$ \\
\hline $\begin{array}{l}\text { Nurseries in Forest } \\
\text { Districts in northern } \\
\text { Poland }\end{array}$ & nursery-bed soil & $4.95-7.68$ & 900 & 7 & $\begin{array}{l}\text { Suillus grevillei. Wilcoxina } \\
\text { mikolae }\end{array}$ & L. decidua & $\begin{array}{l}\text { Leski, et al., } 2008 \\
{[38]}\end{array}$ \\
\hline $\begin{array}{l}\text { North of the city of } \\
\text { Wiesbaden, Hesse, } \\
\text { Germany }\end{array}$ & $\begin{array}{l}\text { loess-loam with quarzit } \\
\text { and clay shale }\end{array}$ & ns & ns & 15 & $\begin{array}{c}\text { Cenococcum geophilum, Genea } \\
\text { hispidula, Laccaria amethystina, } \\
\text { Russula ochroleuca, Xerocomus } \\
\text { chrysenteron }\end{array}$ & F. sylvatica & $\begin{array}{c}\text { Schauf and Rothe, } \\
1996 \\
{[37]}\end{array}$ \\
\hline $\begin{array}{l}\text { National Park Hainich, } \\
\text { Thuringa, Germany }\end{array}$ & $\begin{array}{l}\text { Luvisol that had devel- } \\
\text { oped from loess }\end{array}$ & 5.3 & 340 & 78 & $\begin{array}{c}\text { Clavulina cristata, Lactarius } \\
\text { subdulcis, Tomentella } \\
\text { sublilacina }\end{array}$ & F. sylvatica & $\begin{array}{c}\text { Lang, et al., } 2011 \\
{[36]}\end{array}$ \\
\hline $\begin{array}{c}\text { Merzalben Forest District } \\
\text { near the city of Trippstadt, } \\
\text { Rhineland-Palatinate, } \\
\text { Germany }\end{array}$ & $\begin{array}{l}\text { Sparse podsoil-brown } \\
\text { earth mix with a humus } \\
\text { compound }\end{array}$ & $\begin{array}{l}4.34 \text { (ls) } \\
3.64 \text { (uls) }\end{array}$ & ns & 75 & $\begin{array}{l}\text { Cenococcum geophilum, } \\
\text { Quecirhiza fibulocystidiata, } \\
\text { Piceirhiza chordate, Lactarius } \\
\text { subdulcis }\end{array}$ & Q. petraea & $\begin{array}{l}\text { Wilson, } 2005 \\
\quad[40]\end{array}$ \\
\hline $\begin{array}{c}\text { Near the city of Potsdam, } \\
\text { Germany }\end{array}$ & sand & ns & ns & 74 & Amanita citrina. & Q. petraea & $\begin{array}{c}\text { Sammler, } 2004 \\
{[41]}\end{array}$ \\
\hline $\begin{array}{c}\text { Taunus Mts.. near the } \\
\text { cities of Königstein and } \\
\text { Taunusstein, Hesse, } \\
\text { Germany }\end{array}$ & Taunus-quarzit & $\begin{array}{l}3.96 \\
3.66 \\
4.78 \\
3.80 \\
4.28\end{array}$ & 734 & 32 & $\begin{array}{c}\text { Paxillus involutus, Russula } \\
\text { ochroleuca }\end{array}$ & $\begin{array}{l}\text { F. sylvatica } \\
\text { Q. petraea } \\
\text { P. abies } \\
\text { L. decidua } \\
\text { A. alba }\end{array}$ & Present study \\
\hline
\end{tabular}

*Not specified; ls = limed soil; uls = unlimed soil; Myc = Mycorrhizal species; Tips = Root tips.

were identified so far. The mycorrhizal spectrum of Picea abies was studied in the Höglwald Forest, near Augsburg [39] and the Taunus Mountains (this study) resulting in the identification of 24 different mycorrhizal species. On Quercus petraea growing at the Palatinate Forest in Rhineland Palatinate [40], forests near the city of Potsdam in Brandenburg [41] and in forests of the Taunus Mountains (this study) all together 125 different mycorrhizal species were determined.

In our study on the occurrence and frequency of mycorrhizal species occurring together with the genus Xerocomus on European beech, European larch, Norway spruce, Sessile oak and Silver fir we were able to identify 22 different mycorrhizal species. Of these 12 were identified on Abies alba, 16 on Fagus sylvatica, 11 on Larix decidua, 13 on Picea abies and 16 on Quercus petraea. These findings indicate that the native tree species at the Taunus Mountains European beech and Sessile oak bear the largest number of mycorrhizal species while the introduced tree species Silver fir and European larch are infected with the lowest number of ectomycorrhizal fungi.

Those mycorrrhizae which infected two and more tree species in the Taunus forests occurred partly in frequentcies deviating by $150 \%$ and more from the mean fre- quency. With respect to Abies alba this was the case with Scleroderma citrinum and Tylopilus felleus. Boletus edulis, Byssocorticium atrovirens, Genea hispidula and Lactarius hepaticus appeared in these frequencies on Fagus sylvatica. On European larch such strong deviations were observed for Lactarius hepaticus and Lactarius tabidus.

In Hessian forest stands the average nitrogen loads made in 2009 under European beech up to $17.1 \mathrm{~kg} \mathrm{~N} / \mathrm{ha}$ and under Norway spruce they added up to $23.6 \mathrm{~kg} \mathrm{~N} / \mathrm{ha}$ [20]. These $\mathrm{N}$-values exceed the threshold values of 5 to $20 \mathrm{~kg} \mathrm{~N} / \mathrm{ha} / \mathrm{yr}$ presently validated as harmless with respect to forest ecosystems. Nitrogen concentrations in upper soils of the five stands which we investigated in the Taunus Mountains increased with stand age from 7.7 \pm 1.6 (P. abies) to $22.6 \pm 14.7 \mathrm{~kg} \mathrm{~N} / \mathrm{ha}$ (Q. petraea).

Nitrogen depositions of 14 to $37 \mathrm{~kg} \mathrm{~N} / \mathrm{ha} / \mathrm{yr}$ in Swiss plots caused an increase of arginine concentrations in spruce foliage [42]. Increased nitrogen compounds in leaves or needles of trees may influence the formation of fruiting bodies by ectomycorrhizal fungi because a proportion of several amino acids is transported back to the roots $[43,44]$ and could act as a signal to stop fruiting body production. Furthermore, fine root biomass of Norway spruce decreased with increasing concentrations 
of nitrogen in soil solutions ( $\mathrm{mg} \mathrm{N} / \mathrm{l}>1$ ) [45]. Since the $\mathrm{N}$-values that we observed in upper soils of the five forest stands in the Taunus Mts. ranged from $\sim 3$ to $\sim 9 \mathrm{mg}$ $\mathrm{N} / \mathrm{l}$ it can be concluded that the number of fine roots of the five tree species growing on these plots is reduced. This might have consequences in respect to the number of mycorrhizal individuals on these trees and therefore nutrient uptake as well as water supply to the trees might be affected. It was also observed that starch concentrations in fine roots of European beech were significantly reduced after eight years of nitrogen application at loads of $20 \mathrm{~kg} \mathrm{~N} / \mathrm{ha} / \mathrm{yr}$ in a field fertilization experiment [46]. Since starch formation in roots depends on the transport of soluble carbohydrates through the phloem and from there from cell to cell, the hyphae of mycorrhizae could suffer under low carbohydrate supply. Lower and probably altered carbohydrate flows from the trees to the mycorrhizal fungi could reduce mycorrhizal growth [18] and the formation of fruiting bodies as well [47].

The most striking effect of increased nitrogen availabilities is the non-appearance of fruit bodies $[48,49]$. "Generalists" among ectomycorrhizal fungi such as Laccaria, Lactarius, Paxillus, Scleroderma and Telephora are less prone to increased $\mathrm{N}$-availabilities as "specialists" like Cortinarius, Suillus and Tricholoma [50]. Except for Paxillus involutus which was found mostly frequent and often, Laccaria amethystina, Lactarius subdulcis, L. hepaticus, L. tabidus and Scleroderma citrium occurred as "rare species" on the plots we investigated in the Taunus indicating that they may be affected by the given N-concentrations in the soil. The "specialists" Suillus and Tricholoma were not found in the Taunus and Cortinarius anomalus occurred very rare. These observations indicate that most of the mycorrhizal species that were observed on deciduous and coniferous trees in the Taunus are in danger to be drastically reduced or even extinct in the long term. There are numerous reports of a decrease in mycorrhizal diversity and abundance in forests. In the Netherlands the average number of ectomycorrhizal species decreased from 71 in 19121954 to 38 in 1973-1983 while saprophytic and parasitic fungi infecting wood increased from 38 to 50 [50]. In Forests near the city of Salzburg (Austria) in 1937110 mycorrhizal species were observed while in 1987 there were only 48 and collaterally the number of saprophytic and parasitic fungi infecting wood increased from 17 to 19 [51]. In the forest region near the city of Darmstadt (Germany) the occurrence of sporocarps belonging to different fungal species decreased from 236 in 19181942 to 137 in 1979-1976 including numerous ectomycorrhizal fungi [52]. Similar results were obtained by Schlechte [53] on Norway spruce growing in the north of the city of Göttingen (Germany) with 21 mycorrhizal species on a stand that was loaded with $23 \mathrm{~kg} \mathrm{~N} / \mathrm{ha} / \mathrm{yr}$ but only 3 species on a site loaded with $42 \mathrm{~kg} \mathrm{~N} / \mathrm{ha} / \mathrm{yr}$.

\section{ACKNOWLEDGEMENTS}

We would like to thank Prof. Dr. Dr. James Robinson Harris (honorary professor at the Institute of Zoology, Johannes Gutenberg-University, Mainz, Germany) for proof reading the manuscript.

\section{REFERENCES}

[1] Smith, S.E. and Read, D.J. (1997) Mycorrhizal symbiosis. 2nd Edition, Academic Press, San Diego. doi:10.1016/B978-012652840-4/50015-2

[2] Anderson, I.C. and Cairney, J.W.G. (2007) Ectomycorrhizal fungi: Exploring the mycelial frontier. FEMS Microbiology Reviews, 31, 388-406. doi:10.1111/j.1574-6976.2007.00073.x

[3] Vogelei, A. and Rothe, G.M. (1991) Vergleichende enzymatische Untersuchungen zum Kohlenhydrat-Stoffwechsel der Feinstwurzeln von Fichten (Picea abies [L.] Karst.) an zwei unterschiedlich stark durch Protonenimmissionen belasteten Standorten (Höglwald und Hils). Forstwissenschaftliche Forschungen (Beiheft zum Forstwissenschaftlichen Centralblatt), 39, 60-67.

[4] Dähne, J., Klingelhöfer, D., Ott, M. and Rothe, G.M. (1995) Liming induced stimulation of amino acid metabolism in mycorrhizal roots of Norway spruce (Picea abies [L.] Karst.). Plant and Soil, 173, 67-77. doi:10.1007/BF00155519

[5] Kleinschmidt, R., Hentschke, I. and Rothe, G.M. (1998) Effect of season and soil treatments on carbohydrate concentrations in Norway spruce (Picea abies [L.] Karst.) mycorrhizae. Tree Physiology, 18, 325-332. doi:10.1093/treephys/18.5.325

[6] Nehls, U., Grunze, N., Willmann, M., Reich, M. and Küster, H. (2007) Sugar for my honey: Carbohydrate partitioning in ectomycorrhizal symbiosis. Phytochemistry, 68, 82-91. doi:10.1016/j.phytochem.2006.09.024

[7] Cavagnaro, T.R. and Martin, A.W. (2010) The role of mycorrhizas in plant nutrition: Field and mutant based approaches. 19th World Congress of Soil Science, Soil Solutions for a Changing World, 1-6 August 2010, Brisbane, 148-151.

http://www.iuss.org/19th\%20WCSS/Symposium/pdf/236 6.pdf

[8] Plassard, C. and Dell, B. (2010) Phosphorus nutrition of mycorrhizal trees. Tree Physiology, 30, 1129-1139. doi:10.1093/treephys/tpq063

[9] Smith, S.E. and Smith, F.A. (2012) Fresh perspectives on the roles of arbuscular mycorrhizal fungi in plant nutrition and growth. Mycologia, 104, 1-13. doi: $10.3852 / 11-229$

[10] Steffens, F., Arendholz, W.R. and Storrer, J.G. (1994) Die Ektomycorrhiza: Eine Symbiose unter der Lupe. Biologie in unserer Zeit, 24, 211-218. doi:10.1002/biuz.19940240423

[11] Agerer, R. (2001) Exploration types of ectomycorrhizae. A proposal to classify ectomycorrhizal mycelial systems 
according to their patterns of differentiation and putative ecological importance. Mycorrhiza, 11, 107-114. http://www.esf.edu/efb/horton/Agerer\%202001.pdf doi:10.1007/s005720100108

[12] Agerer, R. (1987-2002) Colour atlas of ectomycorrhizae. Einhorn Verlag, Schwäbisch Gmünd. http://www.sysbot.biologie.uni-muenchen.de/en/people/a gerer/book ectomyc atlas.html

[13] Strasburger, E., Noll, F. and Schenck, H. (1998) Strasburger-Lehrbuch der Botanik. Spektrum Akademischer Verlag, Heidelberg. doi:10.5962/bhl.title.25240

[14] Kreuzwieser, J., Stulen, I., Wiersema, P. and Vaalburg, W. (2000) Nitrate transport processes in Fagus-LaccariaMycorrhizae. Plant and Soil, 220, 107-117. doi:10.1023/A:1004775230952

[15] Montanini, B., Moretto, N., Soragni, E., Percudani, R. and Ottonello, S. (2002) A high-affinity ammonium transporter from the mycorrhizal ascomycete Tuber borchii. Fungal Genetics and Biology, 36, 22-34. doi:10.1016/S1087-1845(02)00001-4

[16] Hodge, A., Helgason, T. and Fitter, A.H. (2010) Nutritional ecology of arbuscular mycorrhizal fungi. Fungal Ecology, 3, 267-273. doi:10.1016/j.funeco.2010.02.002

[17] Nehls, U., Göhringer, F., Wittulsky, S. and Dietz, S. (2010) Fungal carbohydrate support in the ectomycorrhizal symbiosis: A review. Plant Biology, 12, 292-301. doi:10.1111/j.1438-8677.2009.00312.x

[18] Nilsson, L.O. and Wallander, H. (2003) The production of external mycelium by ectomycorrhizal fungi in a Norway spruce forest was reduced in response to nitrogen fertilization. New Phytologist, 158, 409-416. doi:10.1046/j.1469-8137.2003.00728.x

[19] Trudell, S.A. and Edmonds, R.L. (2004) Macrofungus communities correlate with moisture and nitrogen abundance in two old-growth conifer forests, Olympic National Park, Washington, USA. Canadian Journal of Botany, 82, 781-800. doi:10.1139/b04-057

[20] Waldzustandsbericht (2010) Nordwestdeutsche forstliche Versuchsanstalt, Hessisches Ministerium für Umwelt, Energie, Landwirtschaft und Verbraucherschutz. http://www.nw-fva.de/fileadmin/user upload/Sachgebiet/ Waldzustand Boden/WZE-Berichte/WZB2011 Hessen I nternet-1.pdf

[21] White, T.J., Bruns, T.D., Lee, S. and Taylor, J. (1990) Amplification and direct sequencing of fungal ribosomal RNA genes for phylogenetics. Chapter 38. In: Innis, M., Gelfand, D., Sninsky, J. and White, T.J., Eds., PCR Protocols: A Guide to Methods and Applications, Academic Press, Orlando.

http://nature.berkeley.edu/brunslab/papers/white1990.pdf

[22] Gardes, M. and Bruns, T.D. (1993) ITS primers with enhanced specificity for basidiomycetes-Application to identification of mycorhizae and rusts. Molecular Ecology, 2, 113-118.

doi:10.1111/j.1365-294X.1993.tb00005.x

[23] Haese, A. and Rothe, G.M. (2003) Characterization and frequencies of the IGS1 alleles of the ribosomal DNA of Xerocomus pruinatus mycorrhizae. Forest Genetics, 10, 103-112.
http://www.tuzvo.sk/files/fg/volumes/2003/FG10-2 103110--str105.pdf

[24] Doyle, J.J. and Doyle, J.A. (1987) A rapid DNA isolation procedure for small quantities of fresh leaf tissue. Phytochemical Bulletin, 19, 11-15. http://irc.igd.cornell.edu/Protocols/DoyleProtocol.pdf

[25] Kõljalg, U., Larsson, K.H., Abarenkov, K., Nilsson, R.H., Alexander, I.J., Eberhardt, U., Erland, S., Høiland, K., Kjøller, R., Larsson, E., Pennanen, T., Sen, R., Taylor, A.F.S., Tedersoo, L., Vrålstad ,T. and Ursing, B.M. (2005) UNITE: A database providing web-based methods for the molecular identification of ectomycorrhizal fungi. New Phytologist, 166, 1063-1068. doi:10.1111/j.1469-8137.2005.01376.x

[26] Shannon, C.E. and Weaver, W. (1949) The mathematical theory of communication. University of Illinois Press, Urbana.

[27] Wiener, N. (1949) The interpolation, extrapolation, and smoothing of stationary time series. Wiley, New York.

[28] Pielou, E.C. (1966) The measurement of diversity in different types of biological collections. Journal of Theoretical Biology, 13, 131-144. doi:10.1016/0022-5193(66)90013-0

[29] Ulrich, B. (1986) Natural and anthropogenic components of soil acidification. Zeitschrift für Pflanzenernährung und Bodenkunde, 149, 702-717. doi:10.1002/jpln.19861490607

[30] Nylund, J.E., Dahlberg, A., Hogberg, N., Karen, O., Grip, K. and Jonsson, L. (1995) Methods for studying species composition of mycorrhizal fungal communities in ecological studies and environmental monitoring. In: Bonfante, P., Nuti, M. and Stocchi, V., Eds., Biotechnology of Ectomycorrhizae, Plenum Press, New York, 229-240. doi:10.1007/978-1-4615-1889-1 20

[31] Eberhardt, U., Lutz, W. and Kottke, I. (1999) Molecular and morphological discrimination between Tylospora fibrillosa and Tylospora asterophora mycorrhizae. Canadian Journal of Botany, 77, 11-21. doi:10.1139/b98-182

[32] Sakakibara, S.M., Jones, M.D., Gillespie, M., Hagerman, S.M., Forrest, M.E., Simard, S.W. and Durall, D.M. (2002) A comparison of ectomycorrhiza identification based on morphotyping and PCR-RFLP analysis. Mycological Research, 106, 868-878. doi:10.1017/S0953756202006263

[33] Engelmann, H.D. (1978) Zur Dominanzklassifizierung von Bodenarthropoden. Pedobiologia, 18, 378-380.

[34] Cremer, E. (2009) Population genetics of Silver fir (Abies alba Mill.) in the Northern Black Forest-Preconditions for the recolonization of windthrow areas and associated ectomycorrhizal communities. Ph.D. Thesis, Philipp University of Marburg, Marburg.

http://archiv.ub.uni-marburg.de/diss/z2009/0130

[35] Comandini, O., Pacioni, G. and Rinaldi, A.C. (1998) Fungi in ectomycorrhizal associations of silver fir (Abies alba Miller) in Central Italy. Mycorrhiza, 7, 323-328. doi: $10.1007 / \mathrm{s} 005720050200$

[36] Lang, C., Seven, J. and Polle, A. (2011) Host preferences and differential contributions of deciduous tree species 
shape mycorrhizal species richness in a mixed Central European forest. Mycorrhiza, 21, 297-308. doi:10.1007/s00572-010-0338-y

[37] Schauf, M. and Rothe, G.M. (1996) Incidence of mycorrhizae in two beech woods of the Rhein-Main area. Endocytobiosis and Cell Research, 12, 200.

http://zs.thulb.uni-jena.de/servlets/MCRFileNodeServlet/j portal derivate 00100800/ECR 121997 200-200 Schauf.pdf

[38] Leski, T., Aučina, A. and Rudawska, M. (2008) The ectomycorrhizal status of European larch (Larix decidua Mill.) seedlings from bare-root forest nurseries. Forest Ecology and Management, 256, 2136-2144. doi:10.1016/j.foreco.2008.08.004

[39] Qian, X.M., Kottke, I. and Oberwinkler, F. (1998) Influence of liming and acidification on the activity of the mycorrhizal communities in a Picea abies (L.) Karst Stand. Plant and Soil, 199, 99-109. doi:10.1023/A:1004243207414

[40] Wilson, C.A. (2005) Ectomycorrhizae of sessile oak (Quercus petraea (Matt.) Liebl.): Their distribution, abundance and aluminium content with respect to limed and unlimed regions of Merzalben Forest District 04/ 0705, Palatinate Forest, Rheinland-Pfalz, Germany. Ph.D. Thesis, University of Mainz, Mainz. http://ubm.opus.hbz-nrw.de/volltexte/2005/728/index.htm 1

[41] Sammler, P. (2004) Die Roteiche (Quercus rubra L., Fagaceae) als stark mykotrophe Gehölzart-Ein Vergleich der Makromyzetenflora unter Roteichen und einheimischen Eichen in der Umgebung von Potsdam, Deutschland. Feddes Repertorium, 115, 102-120. doi:10.1002/fedr.200311030

[42] Quiring, R., Braun, S. and Flückiger, W. (1997) N-deposition, N-nutrition and free amino acids in the foliage of Picea abies (L.) Karst. and Fagus sylvatica L. from Swiss forest stands. The 4th International Symposium on Responses of Plant Metabolism to Air Pollution and Global Change, 1-5 April 1997, Egmond aan Zee, 56.

[43] Rennenberg, H., Kreutzer, K., Papen, H. and Weber, P. (1998) Consequences of high loads of nitrogen for spruce (Picea abies) and beech (Fagus sylvatica) forests. New Phytologist, 139, 71-86. doi:10.1046/j.1469-8137.1998.00181.x

[44] He, X.M. and Suzuki, A. (2002) Effect of nitrogen resources and $\mathrm{pH}$ on growth and fruit body formation of
Coprinopsis phlyctidospora. Fungal Diversity, 12, 35-44. http://www.fungaldiversity.org/fdp/sfdp/FD12-35-44.pdf

[45] Matzner, E. and Murach, D. (1995) Soil changes induced by air pollution and their implication for forests in Central Europe. Water Air and Soil Pollution, 85, 63-76. doi:10.1007/BF00483689

[46] Hiltbrunner, E., Thomas, V., Braun, S. and Flückiger, W. (2001) Effects of enhanced nitrogen deposition upon roots and soil variables of beech forests in Switzerland. The 5th International Symposium on "Response of Plant Metabolism to Air Pollution and Global Change", 14 November 2001, Pulawy.

[47] Erland, S. and Taylor, A.F.S. (2002) Diversity of ectomycorrhizal communities in relation to the abiotic environment. In: Van der Heijden, M. and Sanders, I., Eds., The Ecology of Mycorrhizas, Ecological Studies Series, Volume 157, Springer-Verlag, Heidelberg, 163-200.

[48] Brandrud, T.E. (1995) The effects of experimental nitrogen addition on the ectomycorrhizal fungus flora in an oligotrophic spruce forest at Gardsjon, Sweden. Forest Ecology and Management, 71, 111-122. doi:10.1016/0378-1127(94)06088-Z

[49] Wallenda, T. and Kottke, I. (1998) Nitrogen deposition and ectomycorrhizas. New Phytologist, 139, 169-187. doi:10.1046/j.1469-8137.1998.00176.x

[50] Arnolds, E. (1991) Decline of ectomycorrhizal fungi in Europe. Agriculture Ecosystems \& Environment, 35, 209244. doi:10.1016/0167-8809(91)90052-Y

[51] Rücker, T. and Peer, T. (1988) Die Pilzflora des hellbrunner Berges: Ein historischer Vergleich. Berichte des Naturwissenschaftlich-Medizinischen Vereins Salzburg, 9, 147-161.

[52] Grosse-Brauckmann, H. and Grosse-Braukmann, G. (1978) Zur Pilzflora der Umgebung von Darmstadt vor 50 Jahren und heute (ein Vergleich der floristischen Befunde Franz Kellenbachs aus der Zeit von 1918 bis 1942 mit dem gegenwärtigen Vorkommen der Arten). Zeitschrift für Mykologie, 44, 257-269.

[53] Schlechte, G. (1986) Zur Mykorrhizapilzflora in geschädigten Forstbeständen. Zeitschrift für Mykologie, 52, 225-232.

http://www.dgfm-ev.de/sites/default/files/ZM521225Schl echte.pdf 


\section{APPENDIX}

Table A1. Accession numbers of ITS-sequences of ectomycorrhizal fungi studied in five forest stands in the Taunus Mts.

\begin{tabular}{cc}
\hline Mycorrhizal species & Accession Number \\
\hline Boletus edulis & JX029999 \\
Byssocorticium atrovirens & JX030000 \\
Cortinarius anomalus & JX030001 \\
Cortinarius casimiri & JX030002 \\
Cortinarius subsertipes & JX030003 \\
Genea hispidula & JX030004 \\
Laccaria amethystina & JX030005 \\
Lactarius hepaticus & JX030006 \\
Lactarius necator & JX030007 \\
Lactarius quietus & JX030008 \\
Lactarius subdulcis & JX030009 \\
Lactarius tabidus & JX030010 \\
Melanogaster variegatus & JX030011 \\
Paxillus involutus & JX030012 \\
Russula ochroleuca & JX030013 \\
Scleroderma citrinum & JX030014 \\
Thelephora terrestris & JX030015 \\
Xerocomilus stuposa & JX030016 \\
\hline
\end{tabular}

